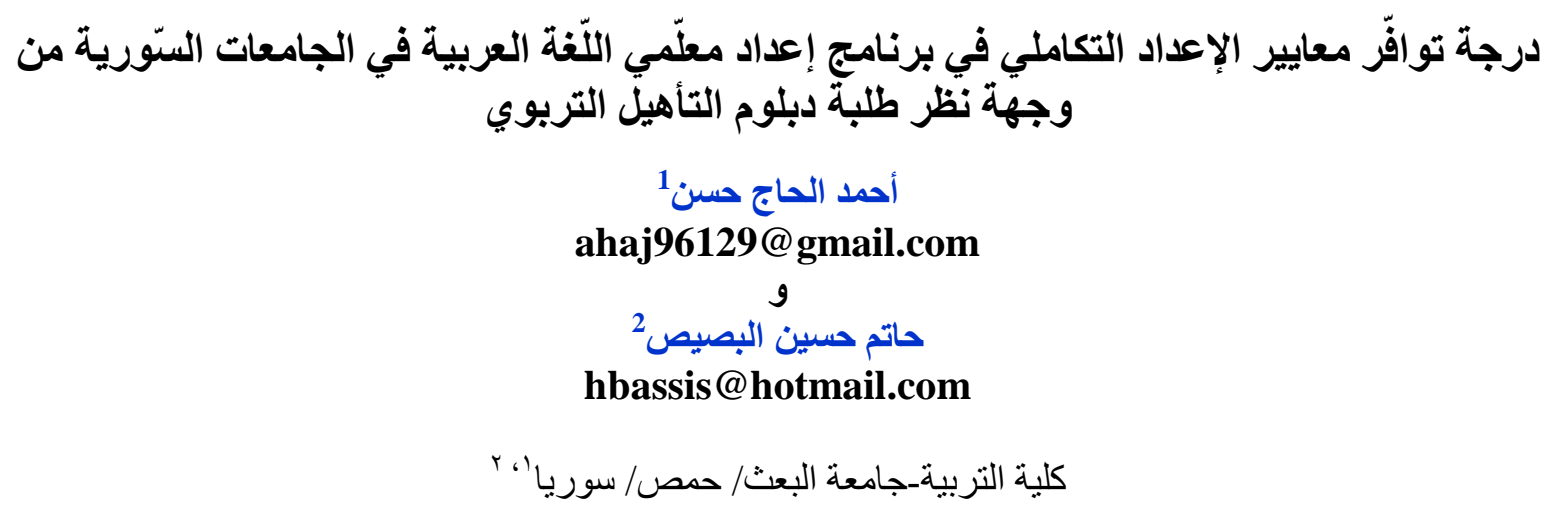

Received: April 9, $2020 \quad$ Accepted: July 2, 2020 Online Published: September 29, 2020 DOI: http://doi.org/10.36231/coeduw/vol31no3.6

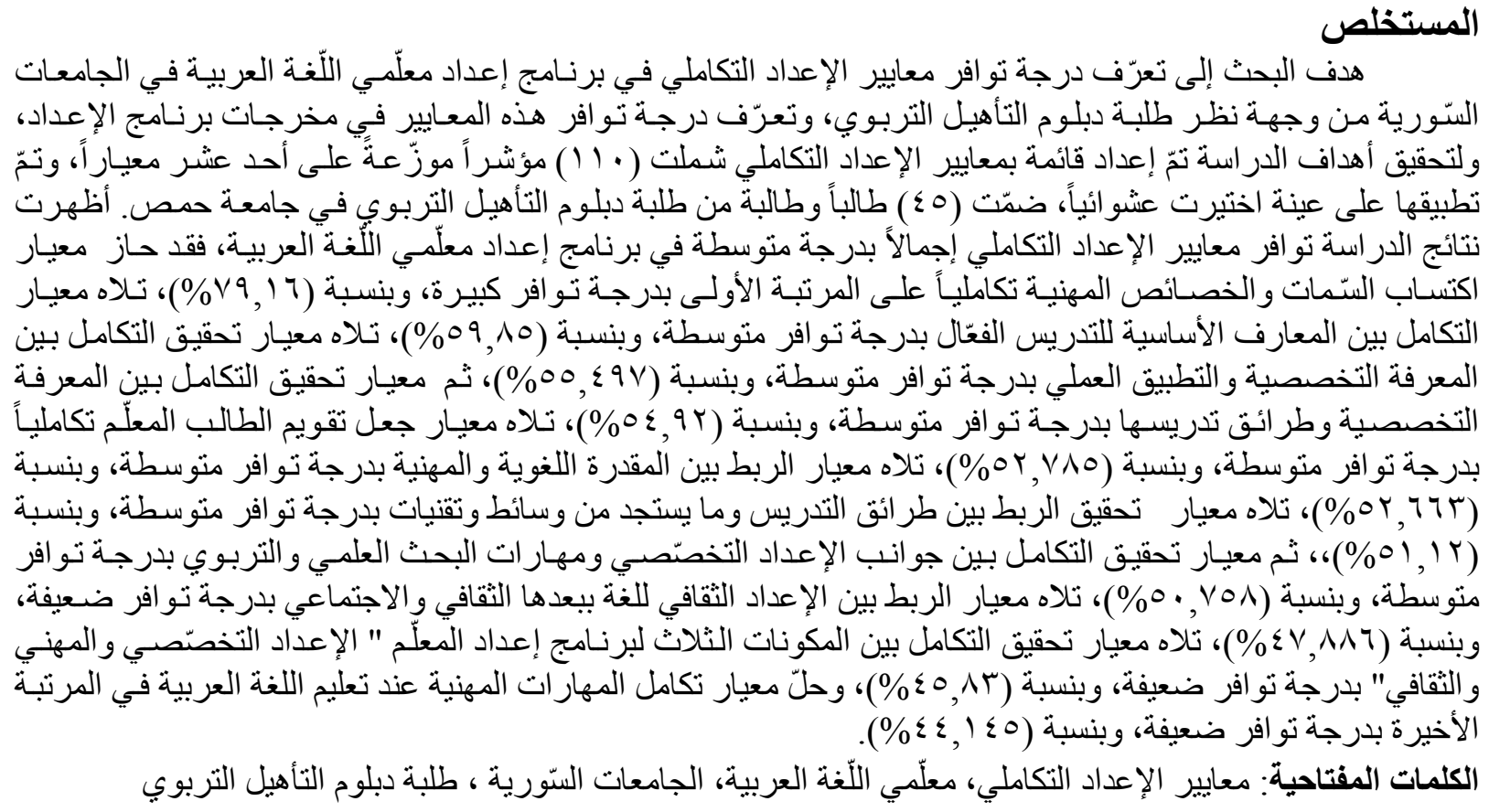

\title{
Degree of Availability of the Integrated Preparation Criteria in Arabic Language Teachers' Preparation Program in Syrian Universities from the Educational Qualification Diploma Students' Viewpoint
}

\author{
Ahmed Rasheed Alhaj Hasan \\ ahaj96129@gmail.com \\ $\&$ \\ Hatem Albassis \\ hbassis@hotmail.com
}

College of Education/ Albaath University/ Hams/ Syria

\section{Abstract}

The study aimed to know the degree of availability of integrated preparation criteria in the Arabic Teacher training Program in Syrian universities from the viewpoint of university students of the Educational qualification diploma, and the degree of availability of these 
standards in the outputs of the preparation program. To achieve the Goals of the study, a list of integrated preparation criteria was prepare comprising (110) indicators, distributed to (11) criteria. The list was applied to a randomly chosen sample of (45) educational qualification diploma students. The results of the study showed that the Standards for integrated preparation are provided in a medium degree overall in the program for preparing teachers of Arabic language. The results of the study showed the availability of standards for integrative preparation as a whole, with a medium degree in the Arabic language teacher's preparation program. The criterion for the integrative acquisition of occupational traits and characteristics ranked first with a high degree of availability, at a rate of (79.16\%). This is followed by the criterion of integration between the basic knowledge of effective teaching with a medium availability, at a rate of $(59.85 \%)$, followed by the criterion of achieving integration between specialized knowledge and practical application with a medium availability rate, at a rate of (55.497\%). Then the criterion for achieving integration between specialized knowledge and methods of teaching it with a moderate degree of availability, and at a rate of (54.92\%). This was followed by the criterion of making the student-teacher evaluation integral with a medium availability degree, at a rate of $(52,785 \%)$, followed by the criterion of linking linguistic and professional ability with a medium availability degree, at a rate of $(52,663 \%)$. This was followed by the criterion of achieving a link between teaching methods and new media and technologies at a medium availability rate, at a ratio of $(51.12 \%)$, then the criterion for achieving integration between aspects of specialized preparation and scientific and educational research skills with a medium availability, and at a rate of $(50,758 \%)$, followed by the criterion of linking The cultural preparation of a language showed its cultural and social dimension with a low availability, at a rate of $(47,886 \%)$, followed by the criterion of achieving integration between the three components of the teacher preparation program, "specialized, professional and cultural preparation" with a low availability, at a rate of (45.83\%), and resolving the standard of integration of professional skills When teaching the Arabic language, it ranked last, with a weak degree of availability, at a rate of $44.145 \%$ ).

Keywords: Integrated Preparation Standards - Arabic Language Teachers Preparation Program - Syrian Universities - Educational Qualification Diploma students.

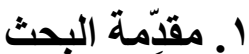

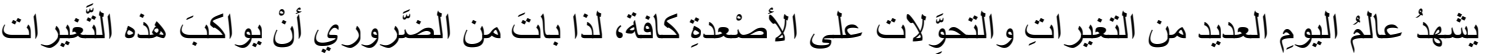

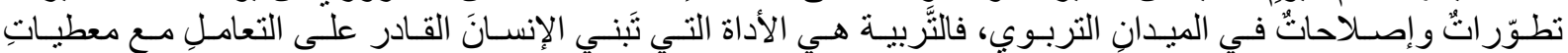

$$
\begin{aligned}
& \text { وخصوصيات هذه التغيرات. }
\end{aligned}
$$

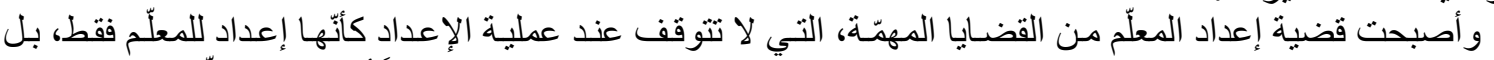

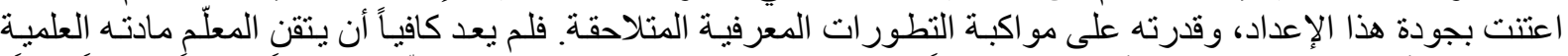

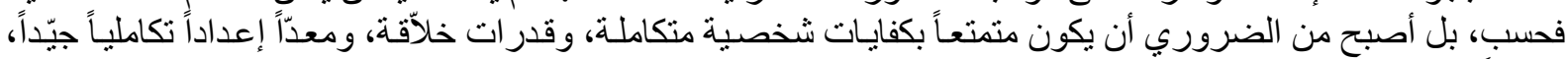

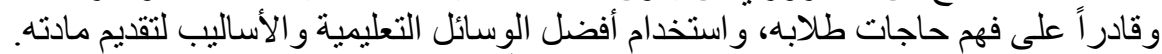

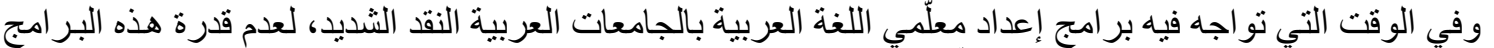

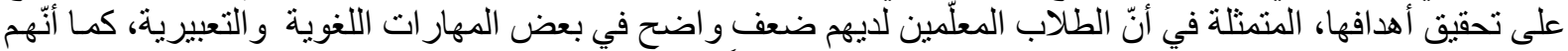

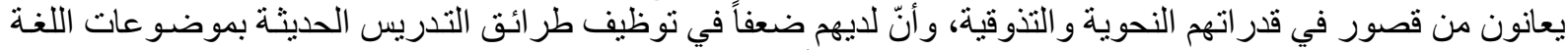

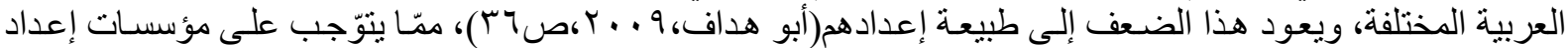

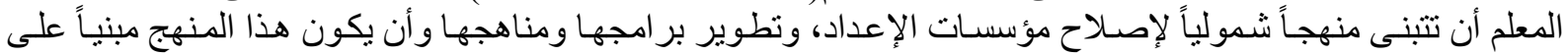

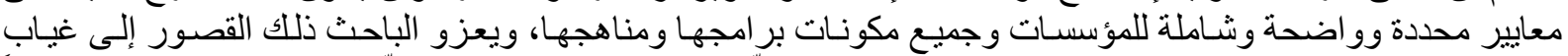

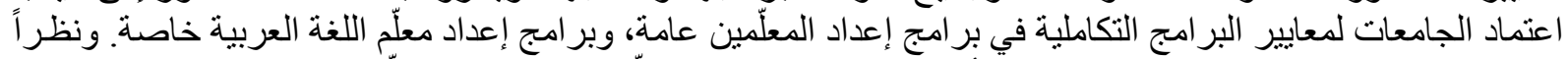

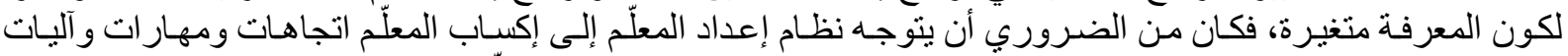

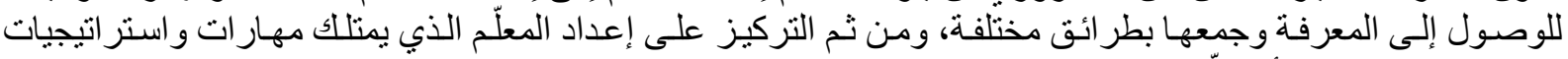

$$
\begin{aligned}
& \text { التدريس من خلال مبدأ التعلّم الذاتي. }
\end{aligned}
$$


ومع انتشار مبادئ الجودة في التعليم، أصبح يُنظر إلى إعداد معلّم اللّغة العربية وتكوينه من منظور هذه المباد المبادئ،

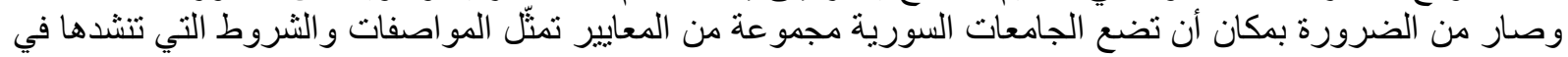

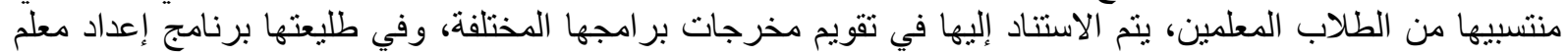

اللغة العربية.

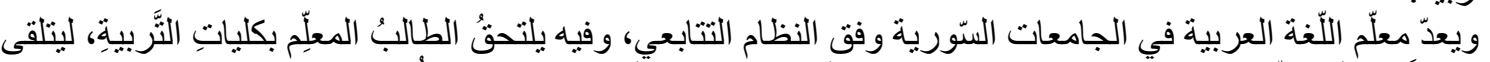

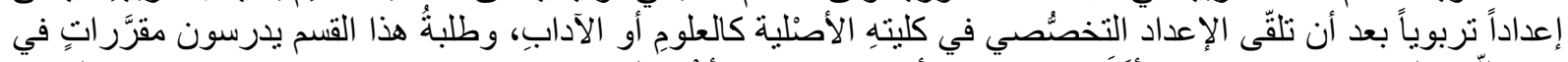

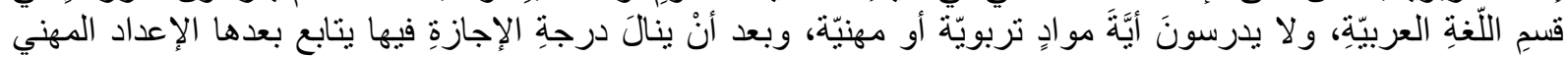

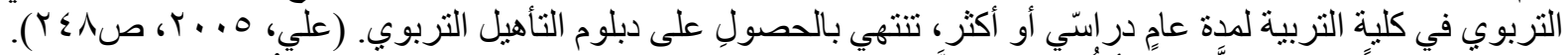

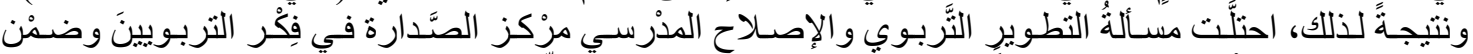

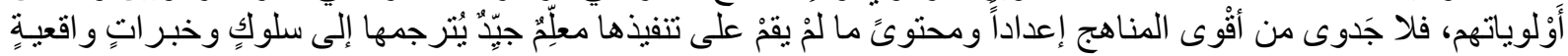

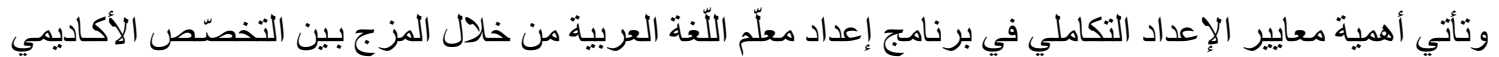

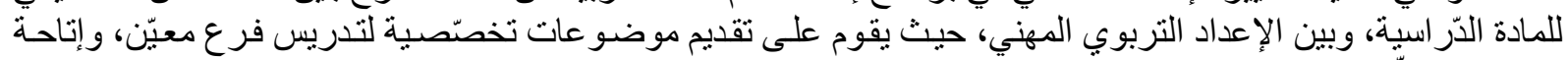

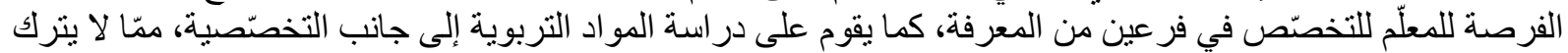

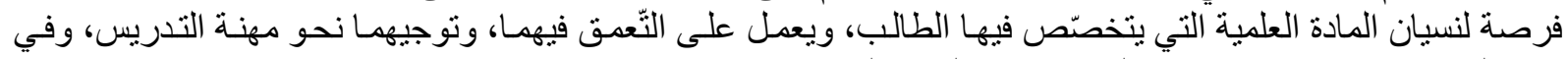

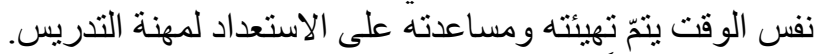

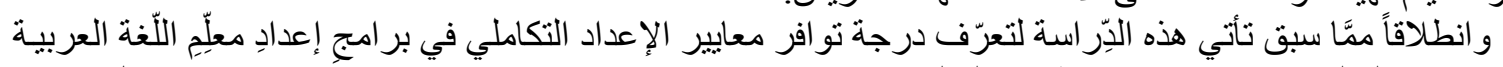

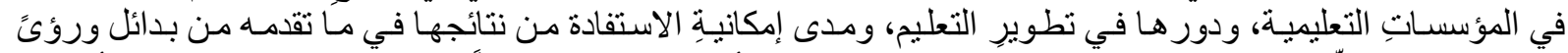

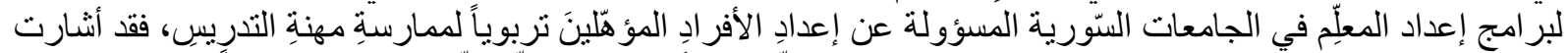

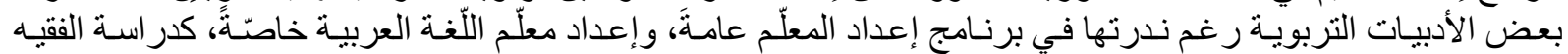

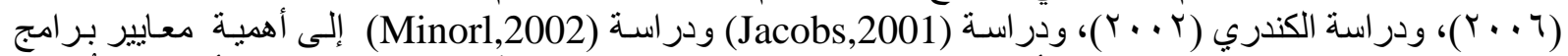

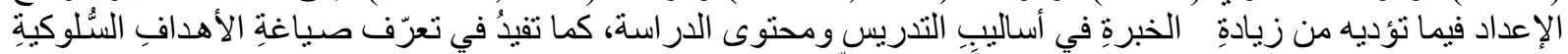

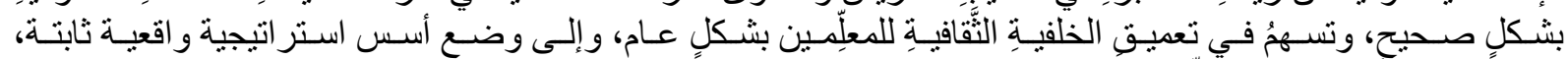

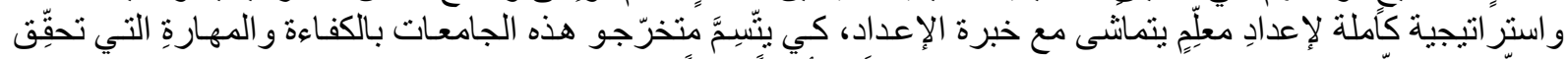

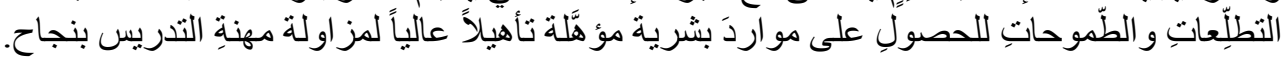

\section{ب ب مشكلة الاراسة}

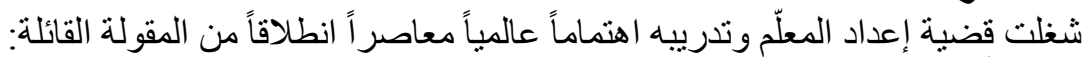

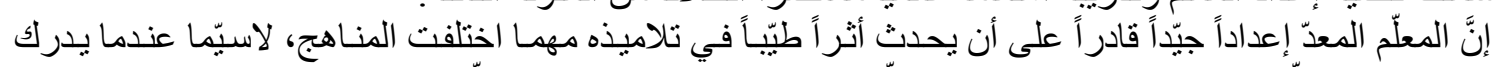

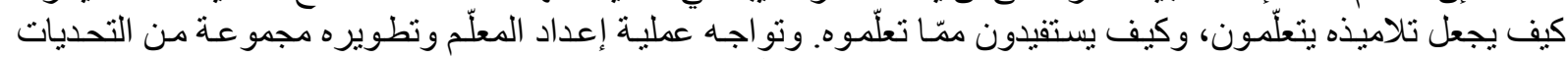

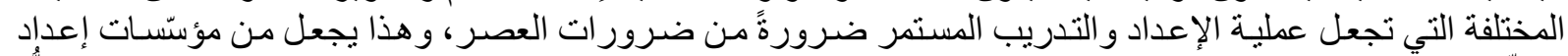

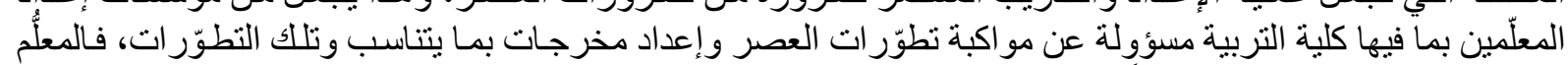

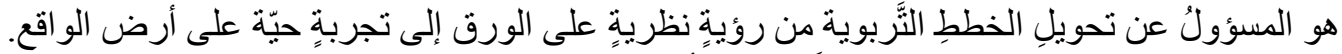

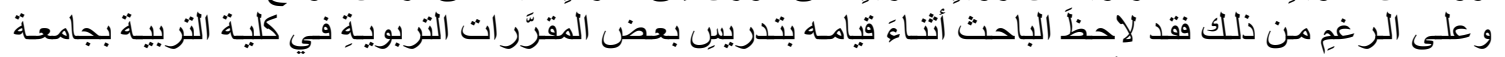

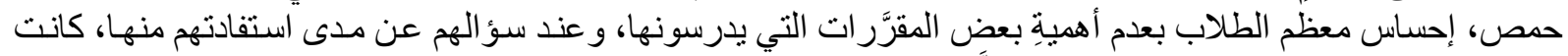

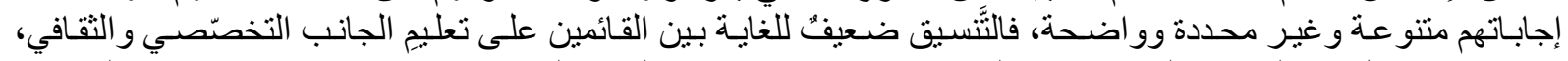

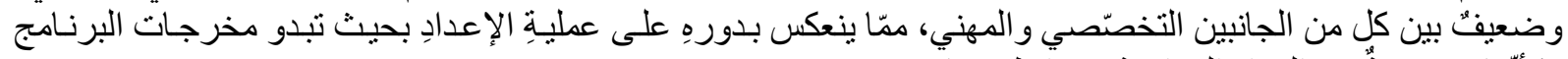

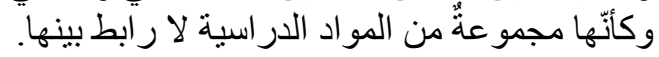

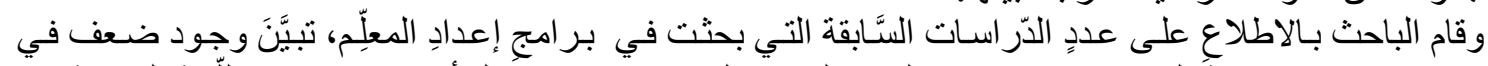

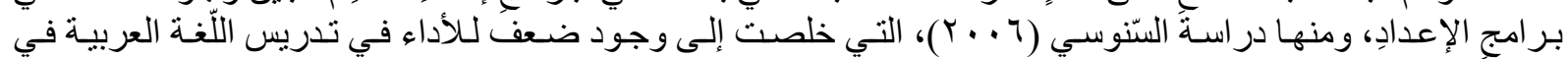

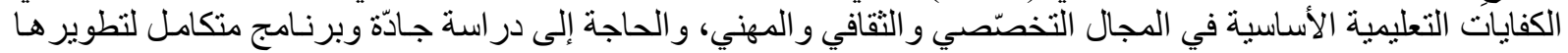

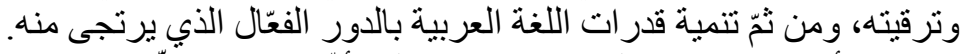

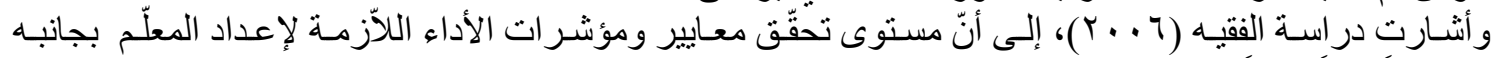

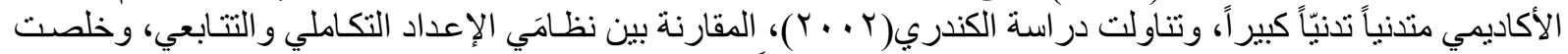

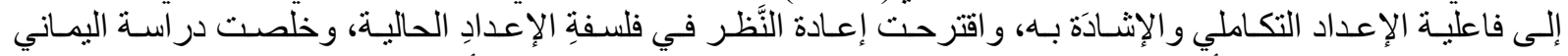

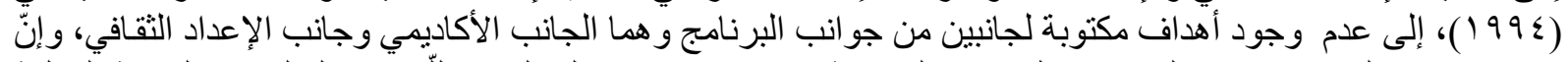

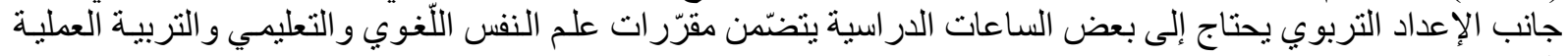




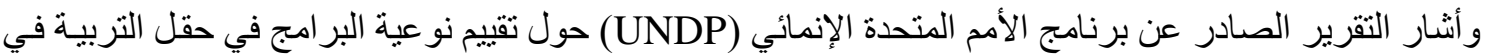

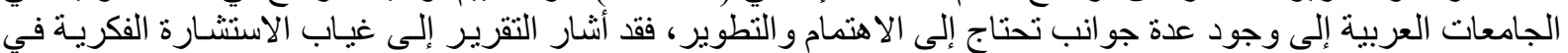

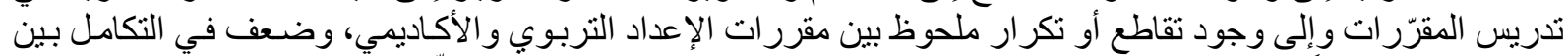

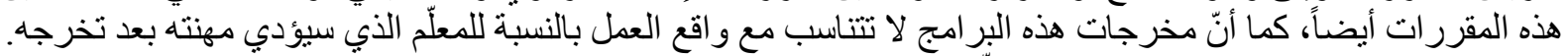

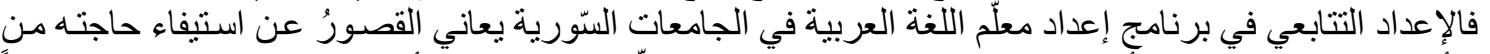

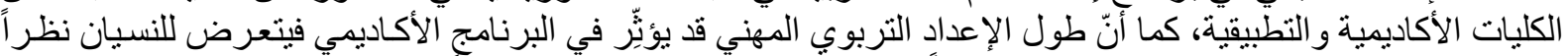

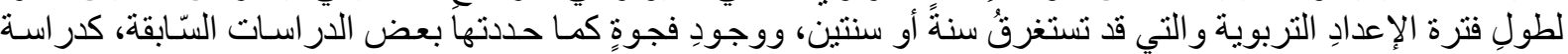

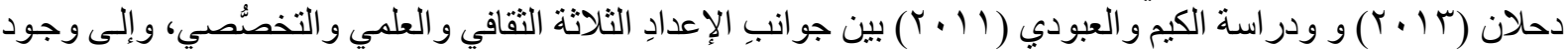

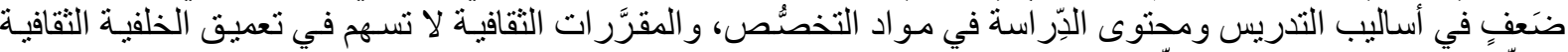

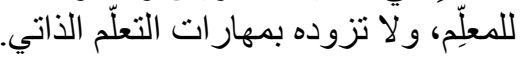

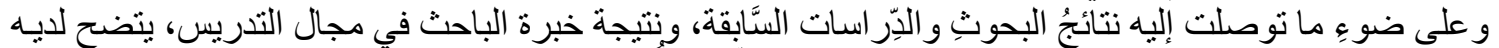

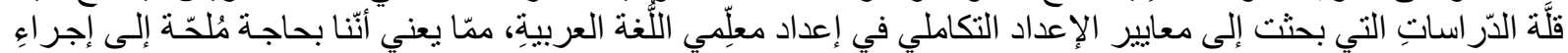

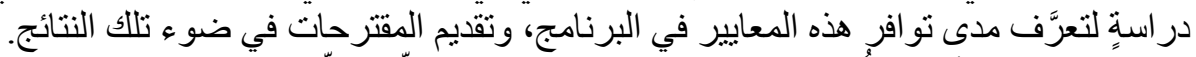

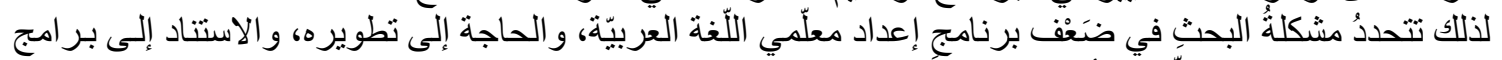

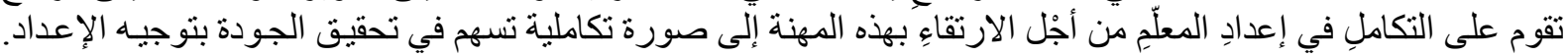
ولحل هذه المشكلة ينبغي الإجابة عن التساؤلات الآتية:

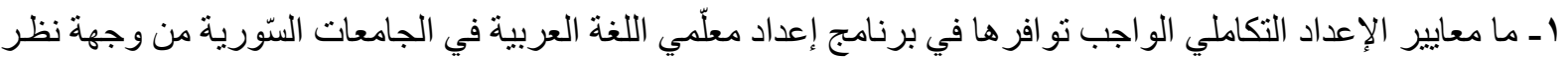

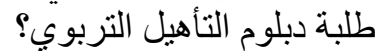

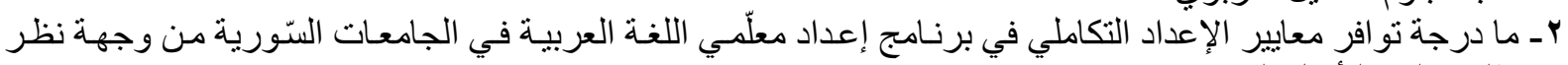
طلبة دبلوم التأهيل التربوي؟

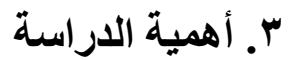

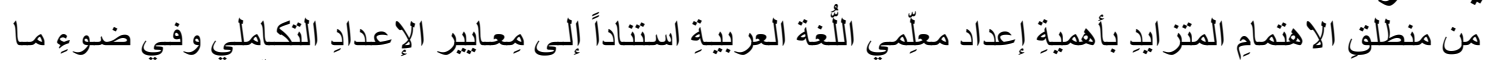

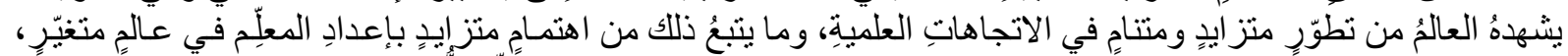

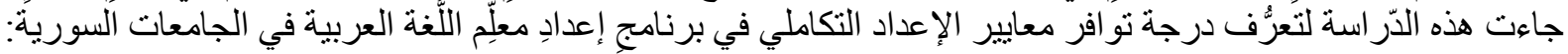

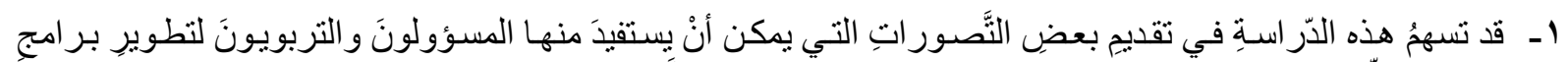

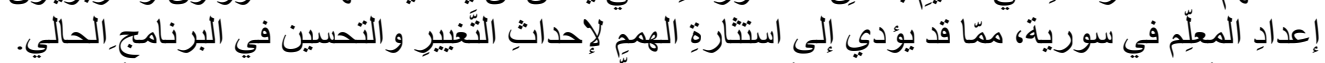

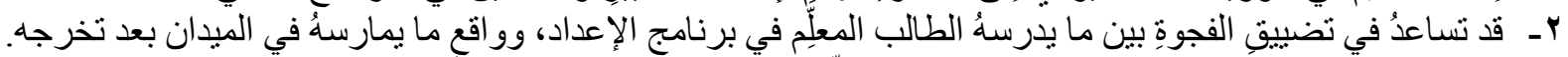

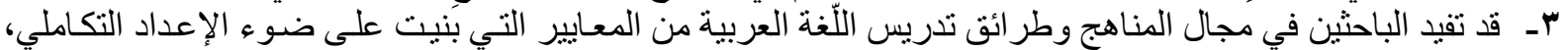

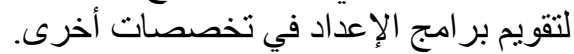

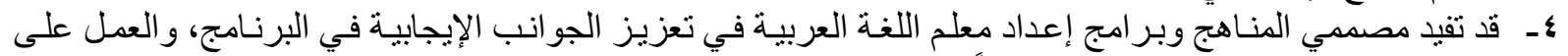

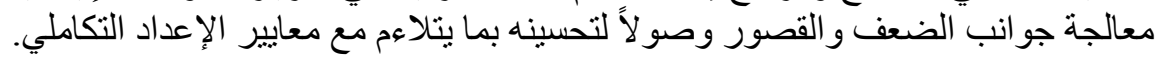

\section{ع. أهداف البحث

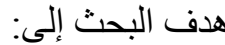

ا ـ تعرّف معايير الإعداد التكاملي في برنامج إعداد معلّمي اللّغة العربية في الجامعات السّورية من وجهة نظر طلبة دبلوم التأهيل التربوي. r- تعرّف درجة تو افر معايير الإعداد التكاملي في برنامج إعداد معلّمي اللغة العربية في الجامعات السّورية من وجهة نظر طلبة دبلوم التأهيل التربوي.

$$
\text { ๑. حدود البحث }
$$

اقتصرت الدر اسة على الدود العد الآتية: • الحدودُ الزمانية: الفصل الأوّل من العام الدر اسئ: 2019 - 2020.

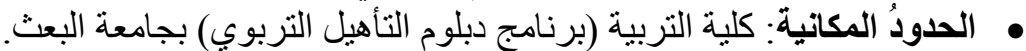

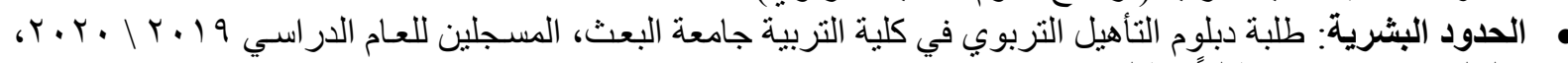
و البالغ عددهم (0 ؛ ) طالباً وطالبة.

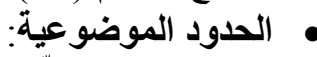

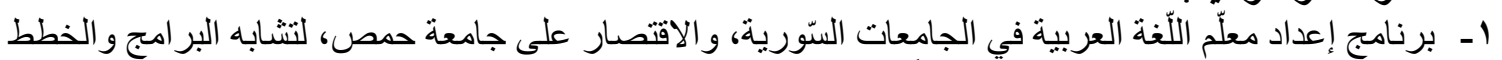

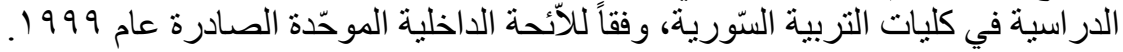




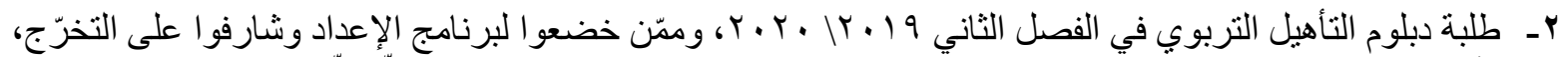

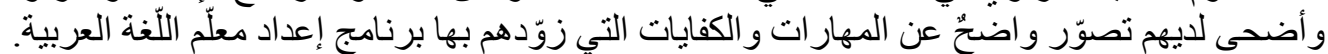

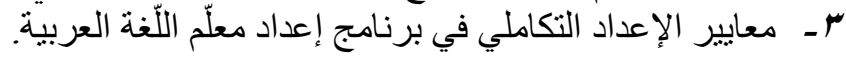

$$
\begin{aligned}
& \text { 7. مصطلحات البحث }
\end{aligned}
$$

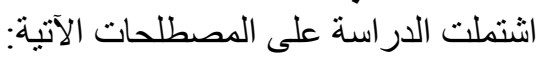

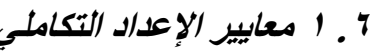

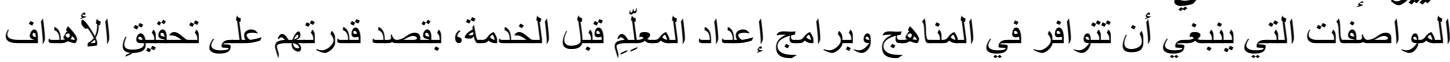

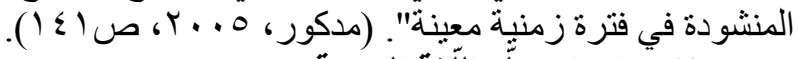

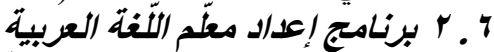

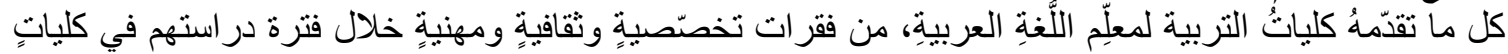

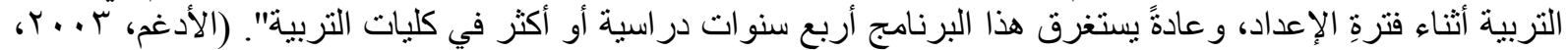

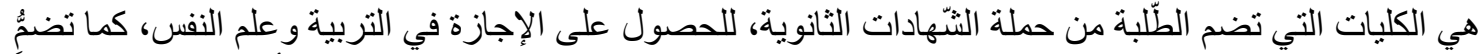

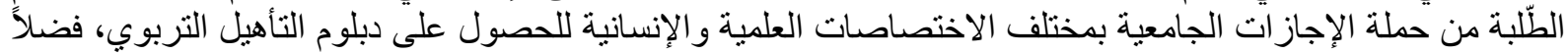

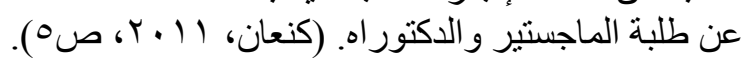

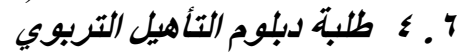

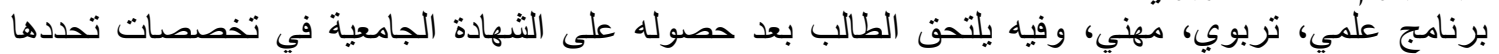
الجامعة، ويهذف إلى تزويد الطلبة بالأسس الفلسفية و التربوية و النفسية، لطر ائق التدريس وتتفنيات التعليم و أساليب التقويم،

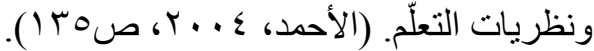

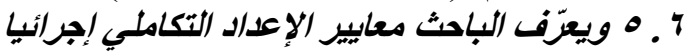

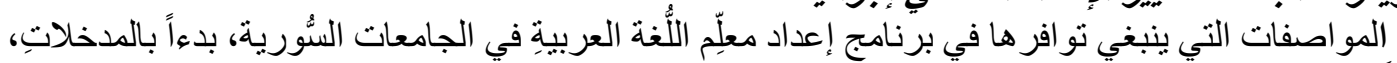

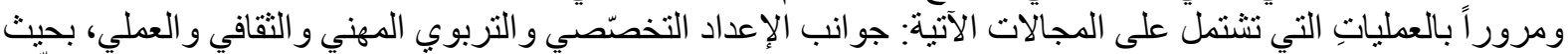

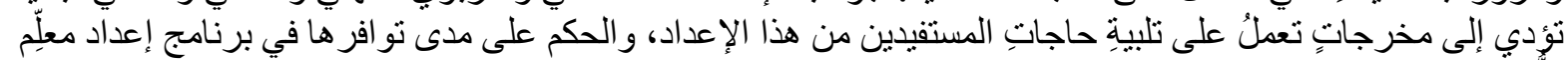

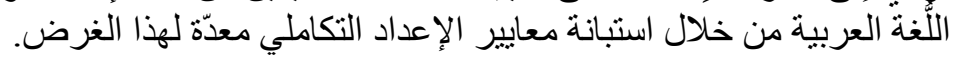

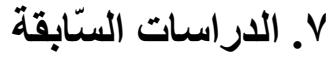

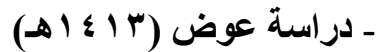

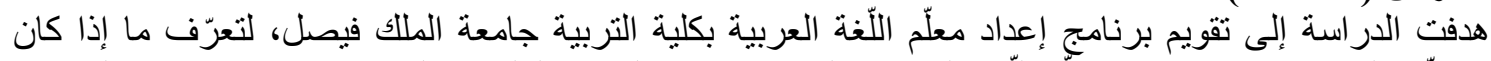

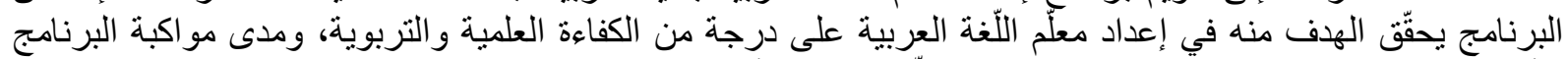

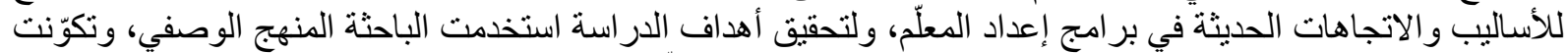

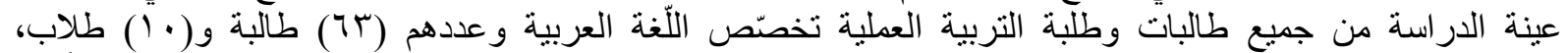

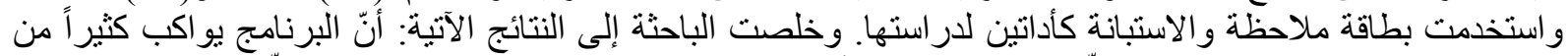

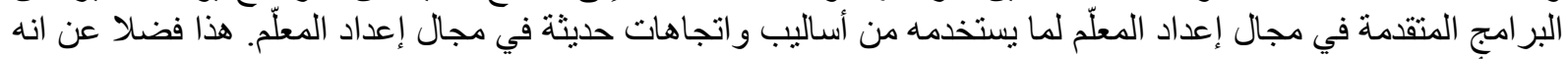

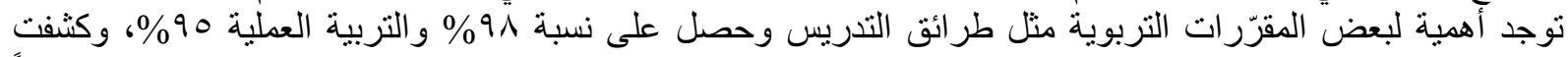

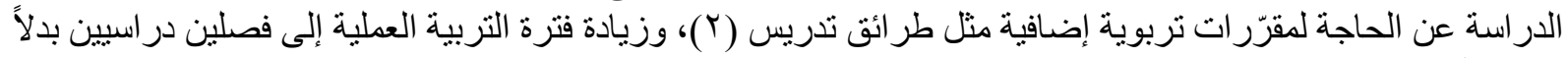

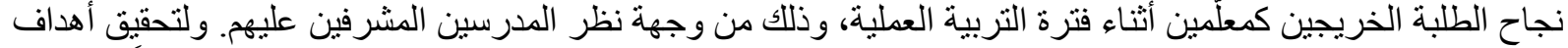

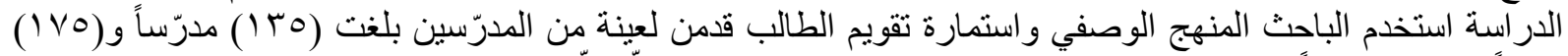

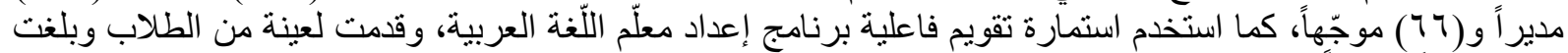

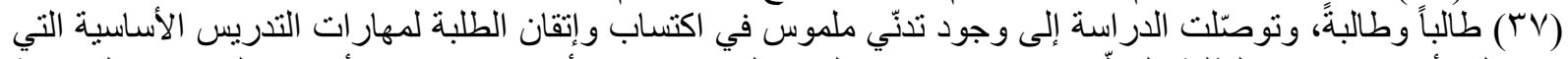

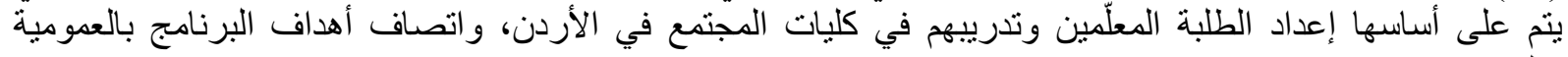

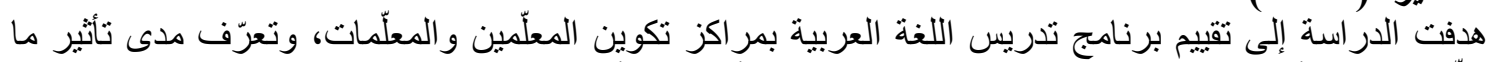

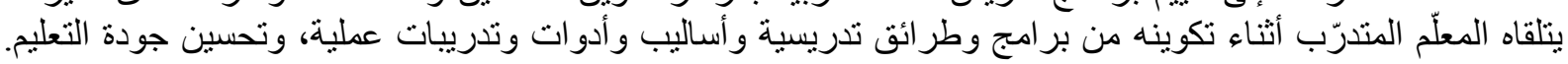


ولتحقيق أهداف الدر اسة استخدمت الباحثة المنهج الوصفي واستمارة اشتملت على عدد من الأسئلة، قدمت إلى أفر اد العينة،

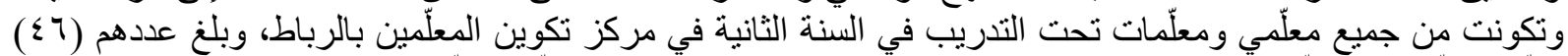

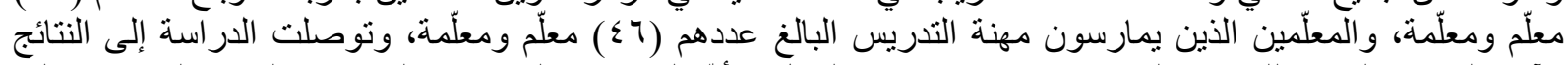

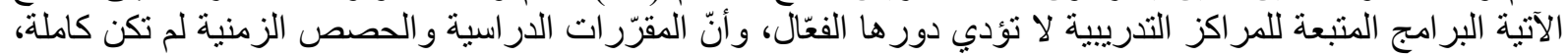

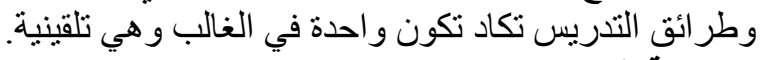

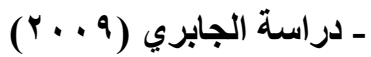

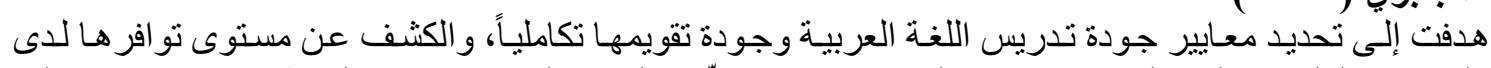

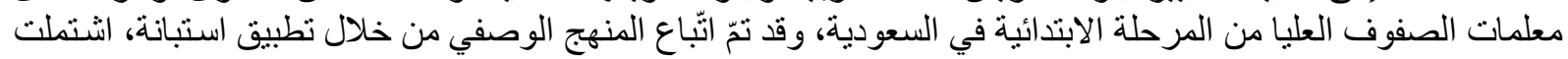

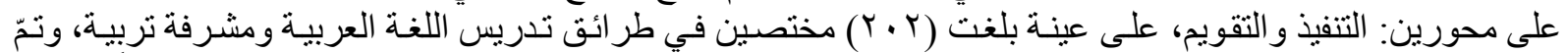

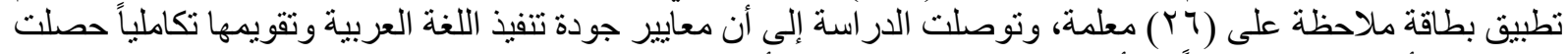

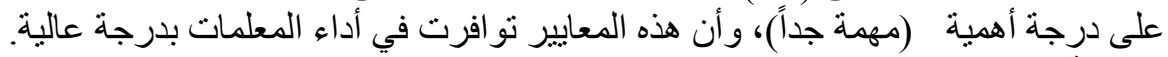

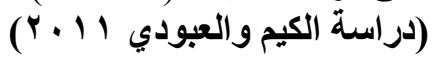

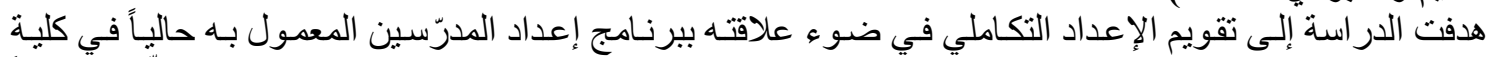

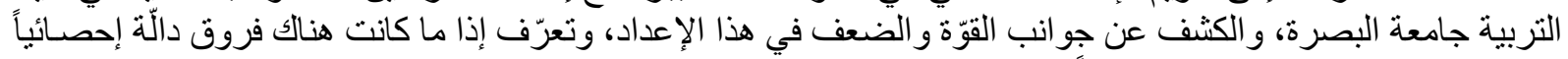

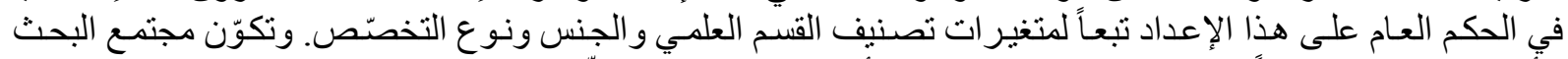

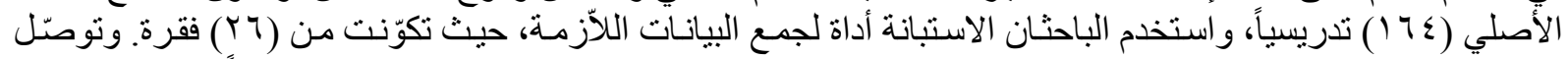

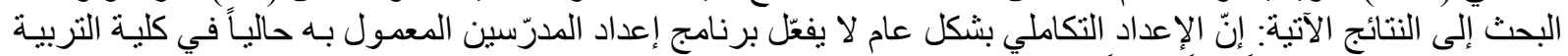

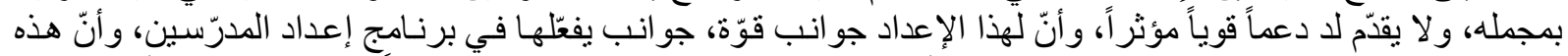

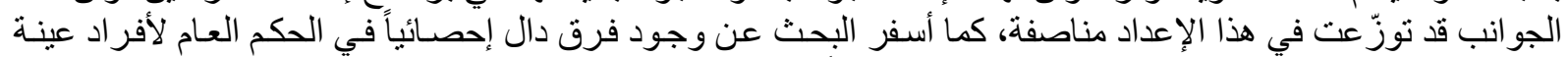

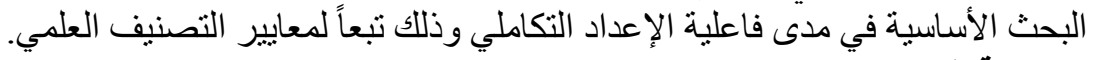

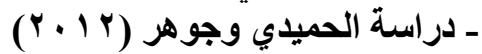

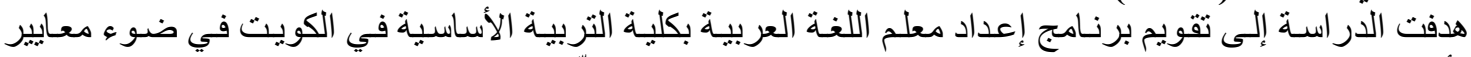

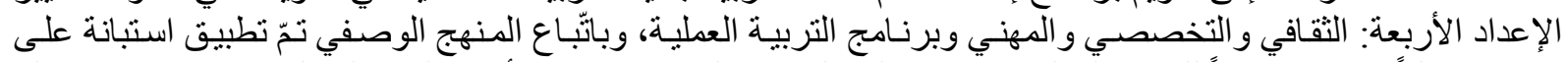

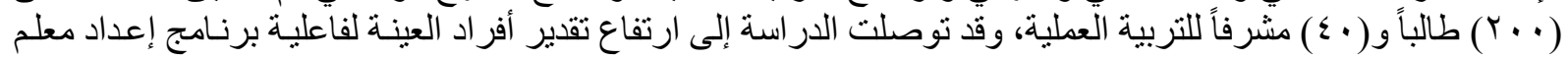

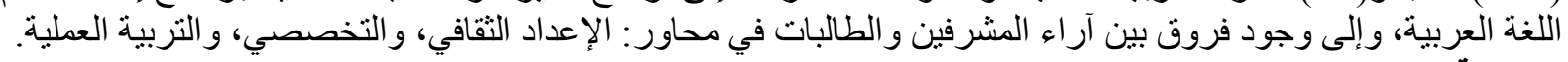

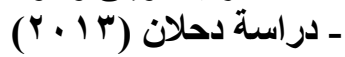

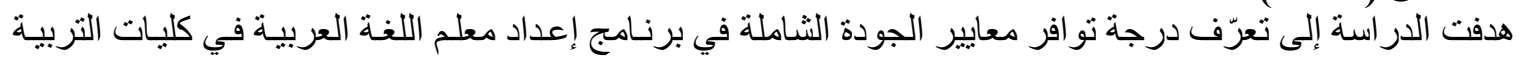

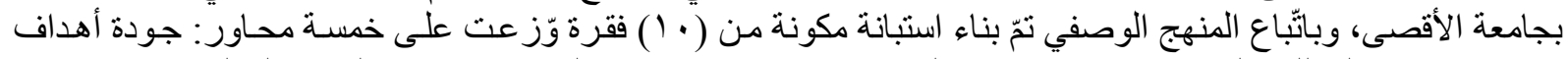

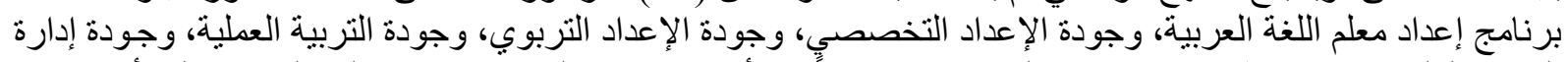

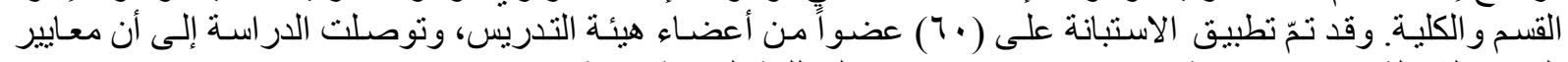

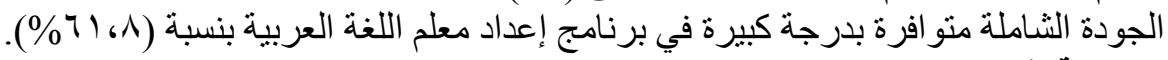

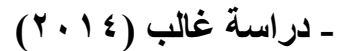

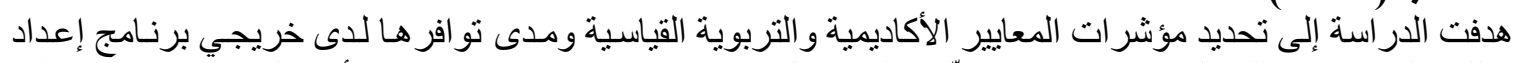

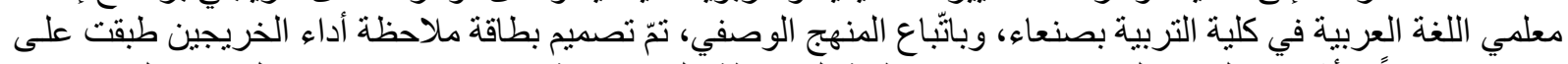

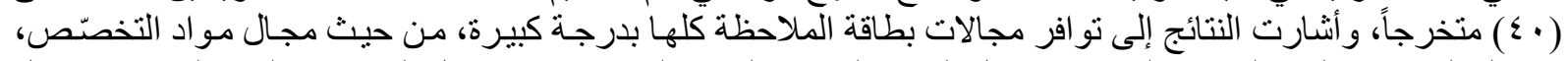

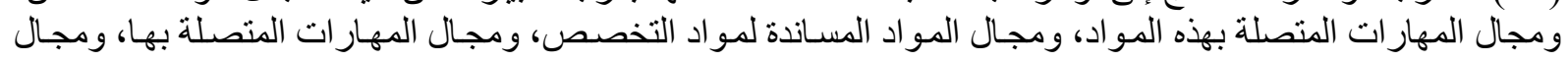

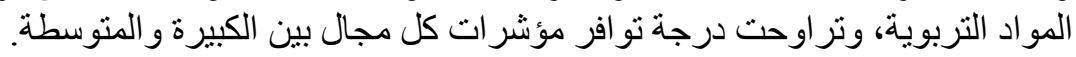
تعقيب على الدراسات السابقة

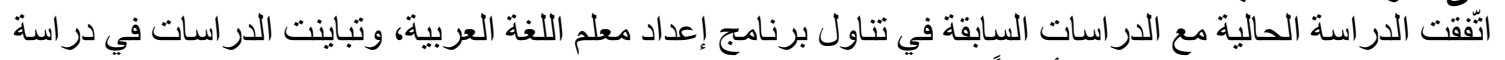

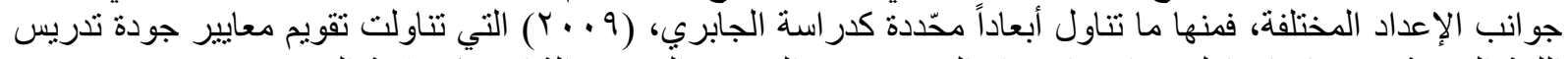

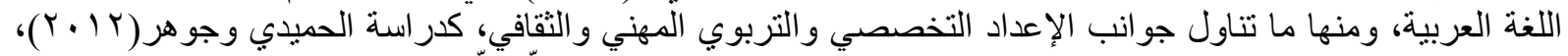

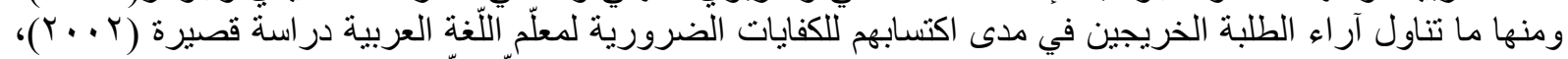

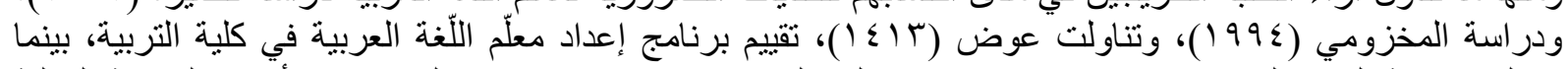

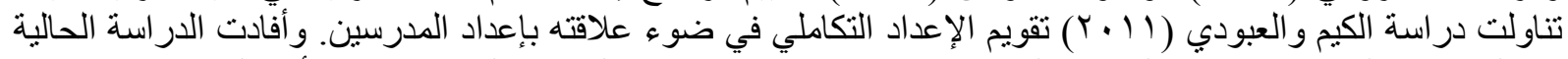

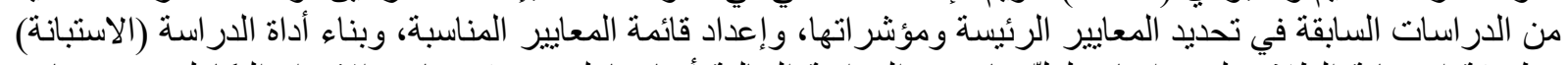

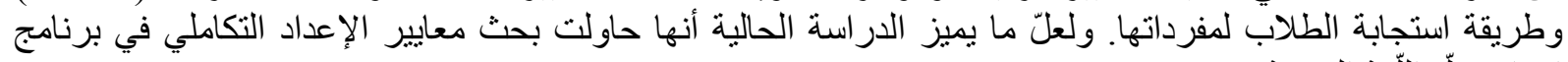
إعداد معلّم اللّغة العربية. 


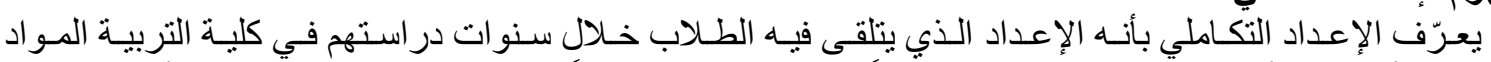

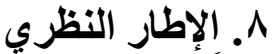

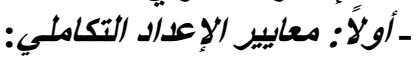

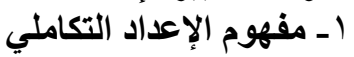

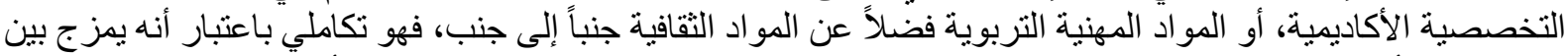

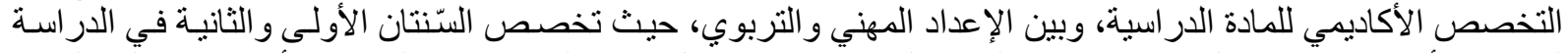

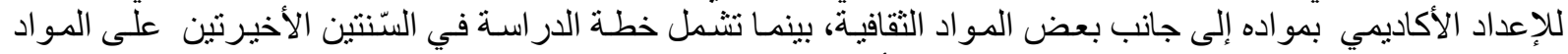

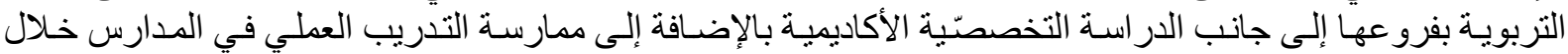

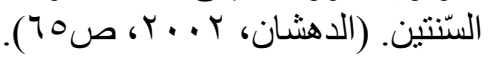

Y ـ معايير الإعداد التكاملي في برنامج إعداد معلّمي اللفة العربية

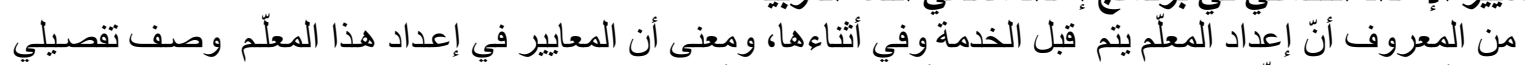

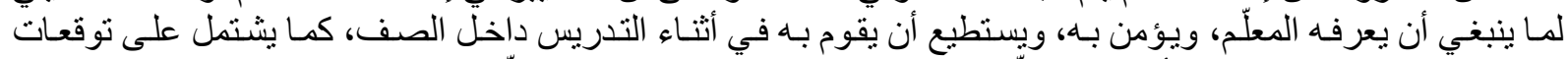

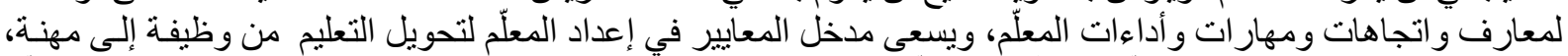

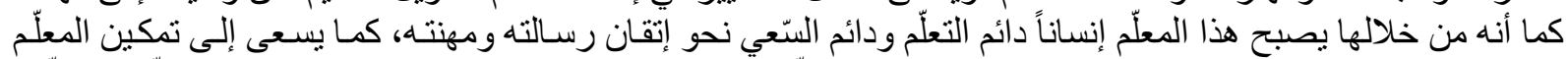

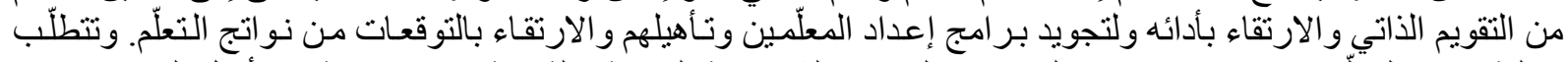

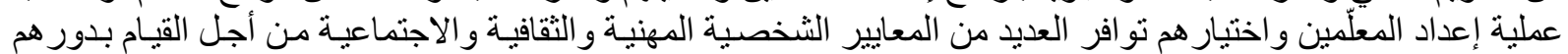

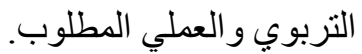

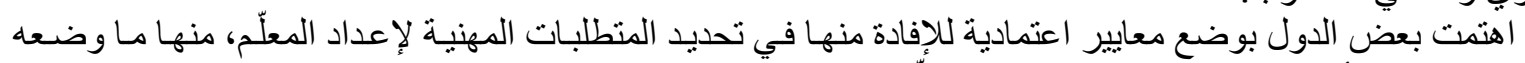

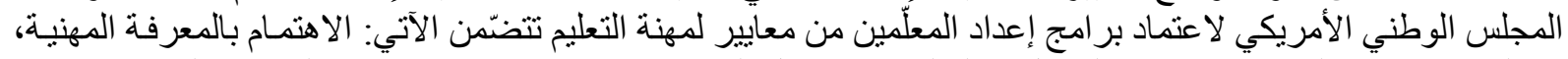

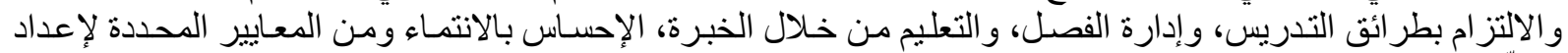

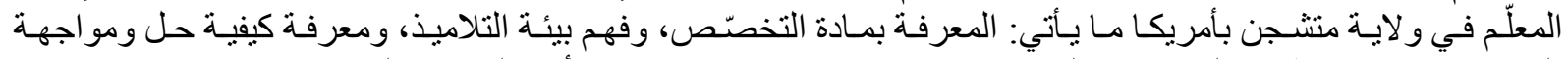

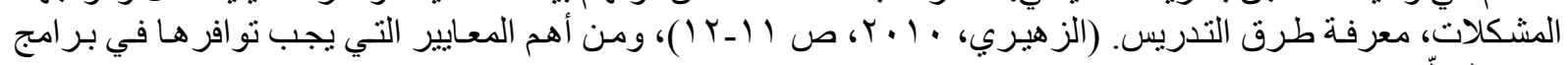

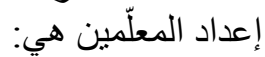

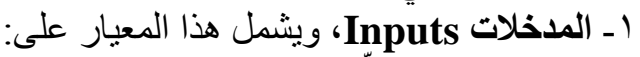

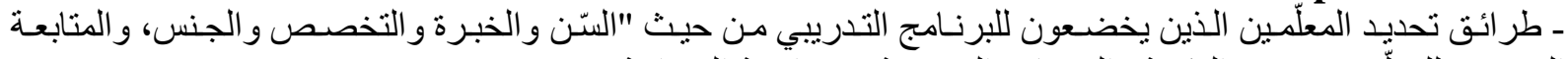

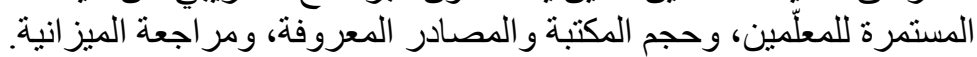

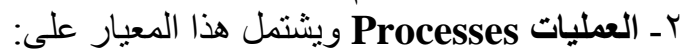

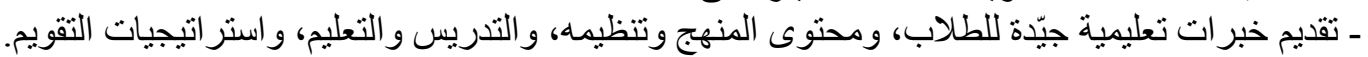

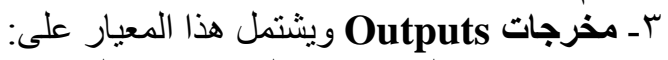

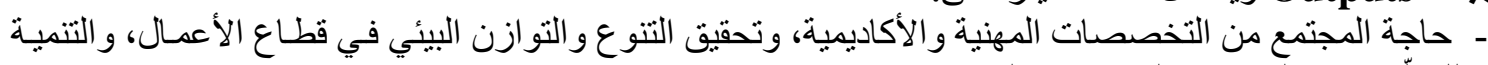

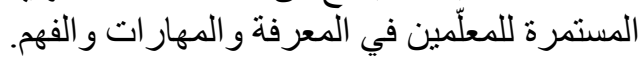

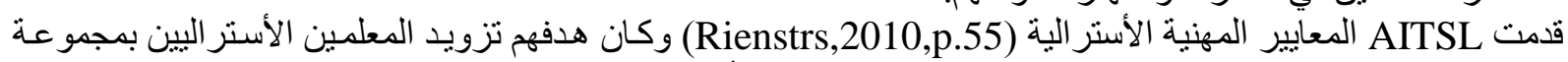

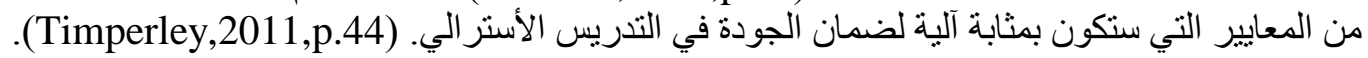

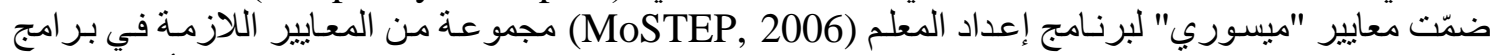

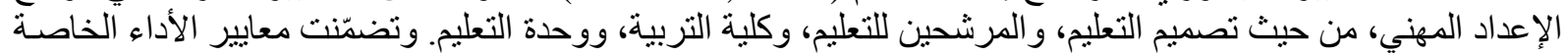

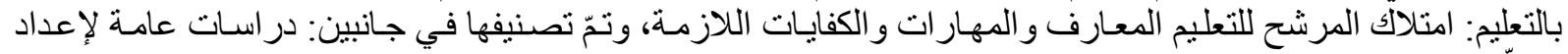

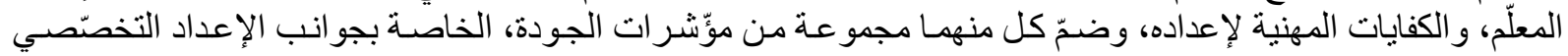

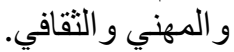

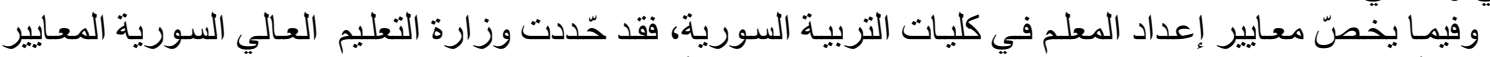

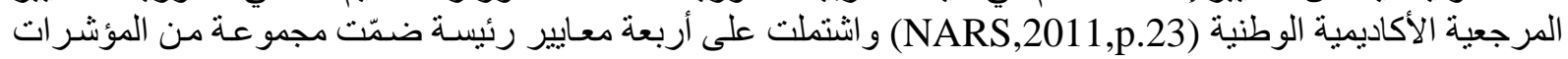

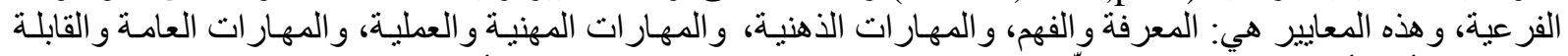

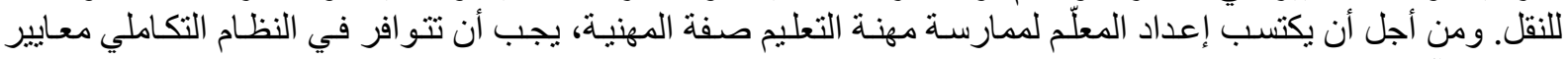

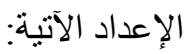

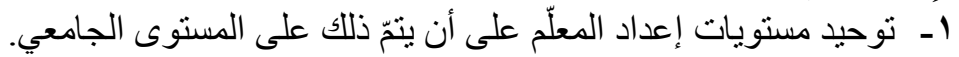

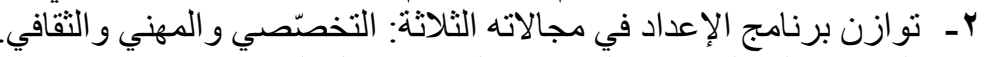

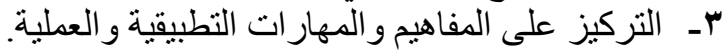




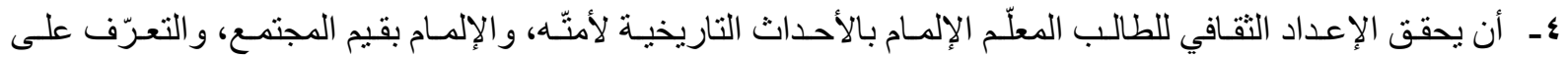
هـ ـ أن يحقق الإعداد التربوي التصني التكامل بين المقرّرات التربوية والتدريب على الوسائل و التقنيات الحديثة في إكساب مهارة

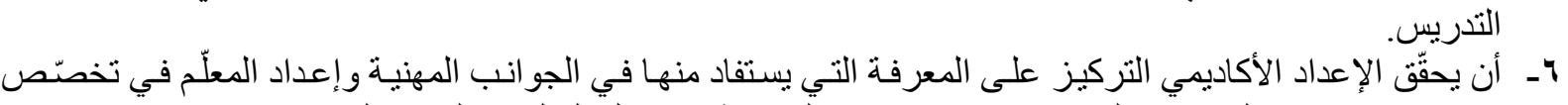

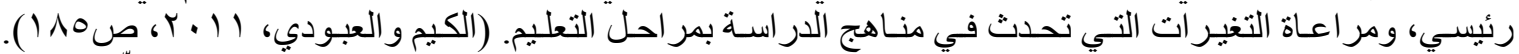

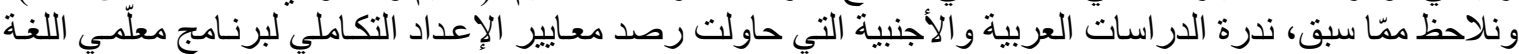

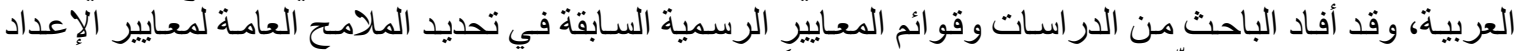

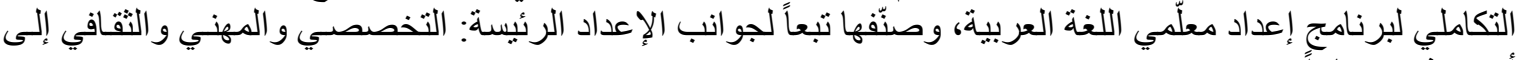

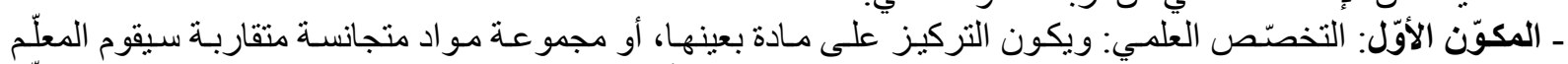

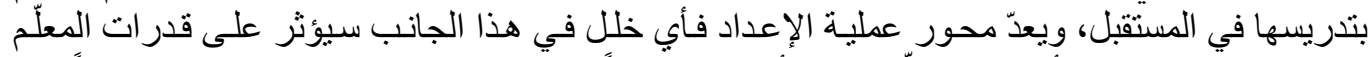

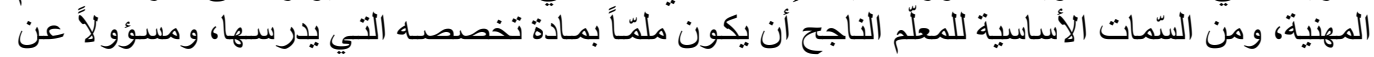

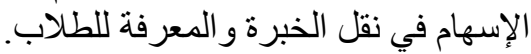

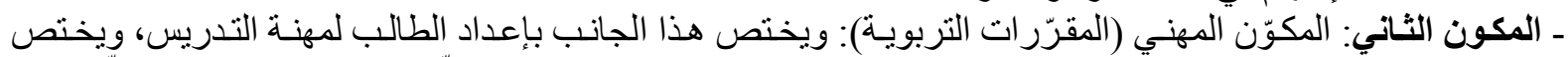

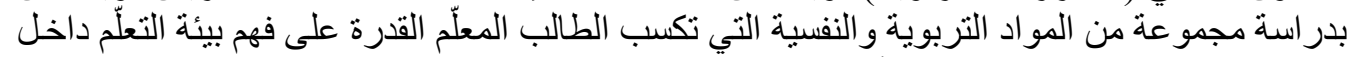

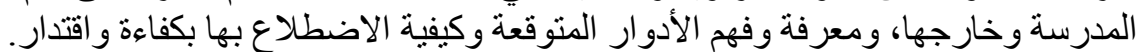

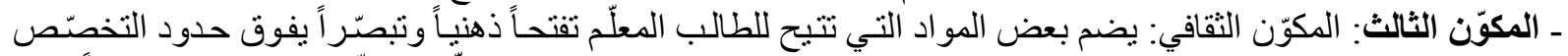

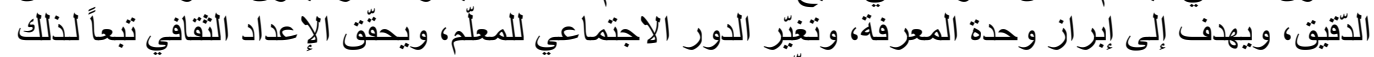

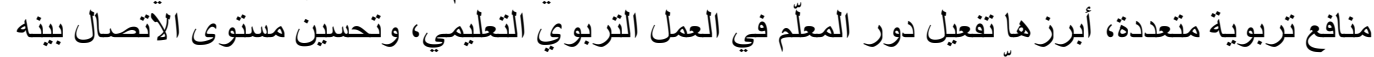

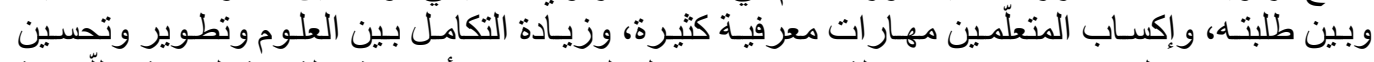

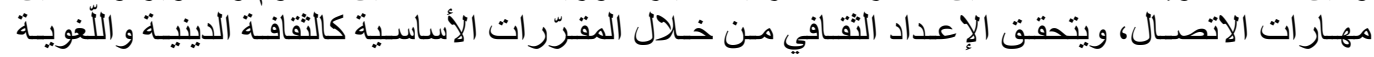
و المجنمعية و العلمية.

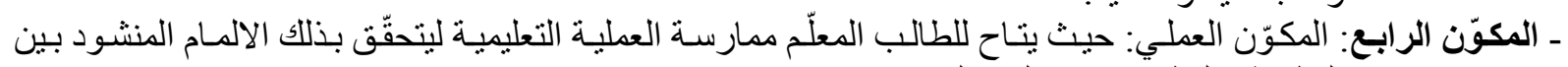

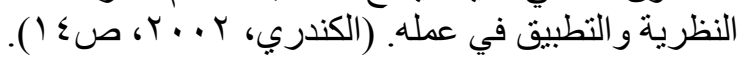

\section{9. تعريف برنامج إعداد معلّم اللّغة العربية}

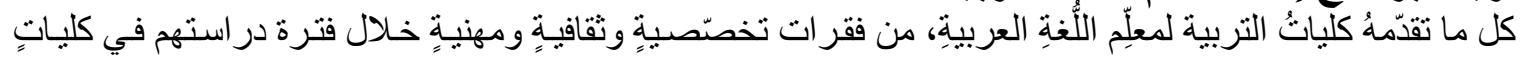

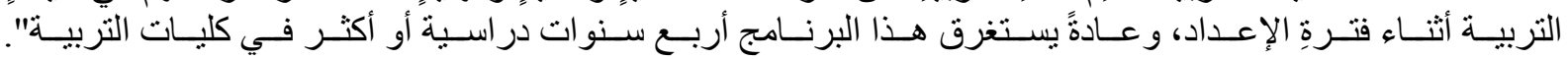

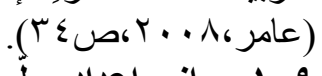

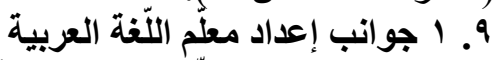

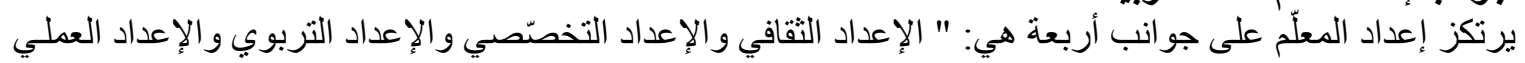
"التربية العملية"" وسيتم توضيحهاد على على النحو الآتي:

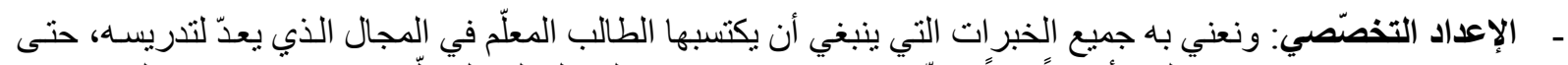

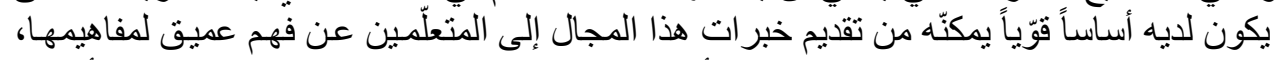

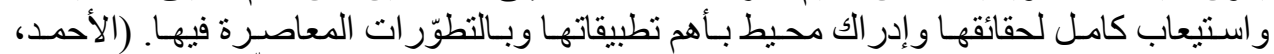

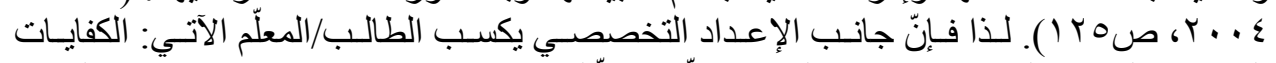

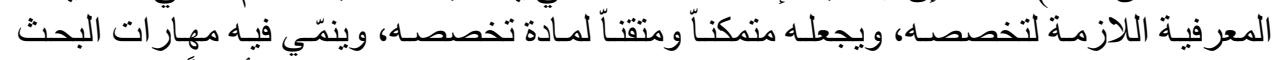

والاطلاع في مادة تخصصه وفي مادة الدر اسات الإسلامية وفي المو اد التربوية أيضاً.

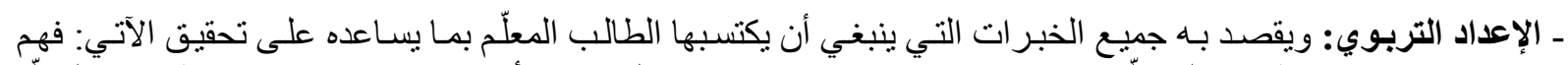

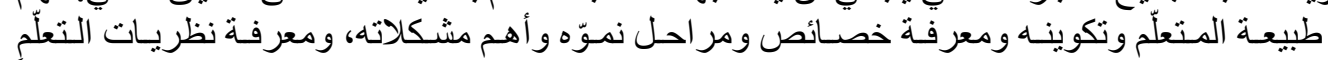

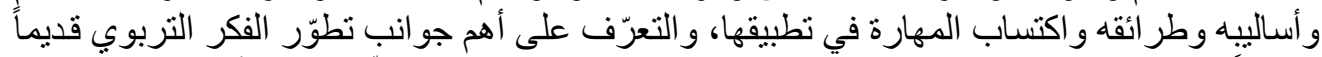

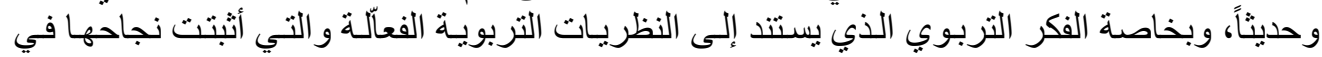


ميدان التجريب. وبناءً على ذلك فإنّ هذا المجال من مجالات الإعداد يجب أن تمكّن معلّم اللغـة العربيـة من:

• الإحاطة بالأهداف التربوية و التعليمية، وتصنيفاتها، و مستو ياتها، وأسس اشتقاقها وصباغتها، و أسس قباسها.

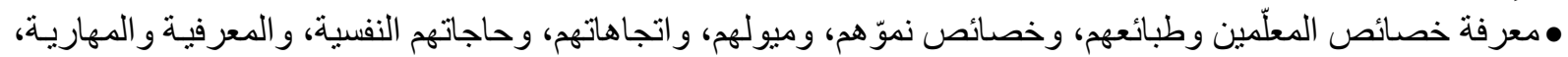

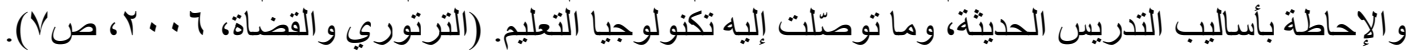

ــ الإعداد الثقافي: يهتم هذا الجانب بثقافة عامة تتيح له التعرّف على علوم أخرى غير تخصّصـهـ و إكسابه الخبرات المتعلّقة

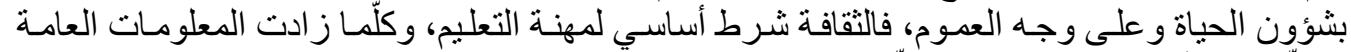

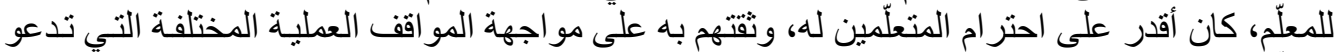

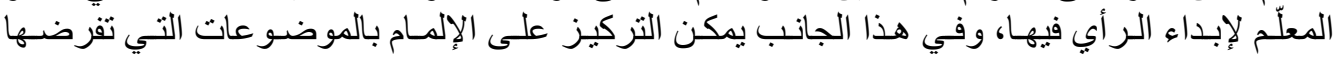

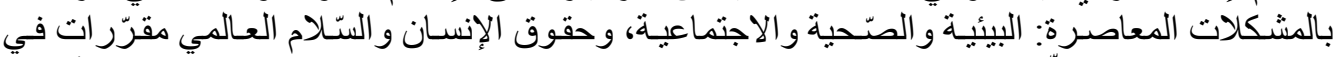

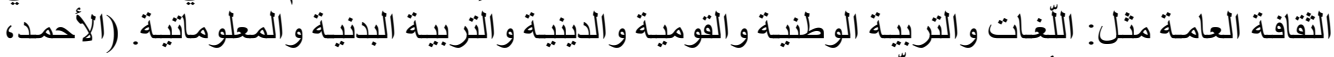

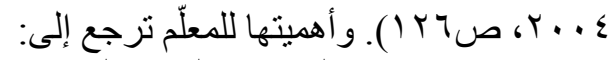

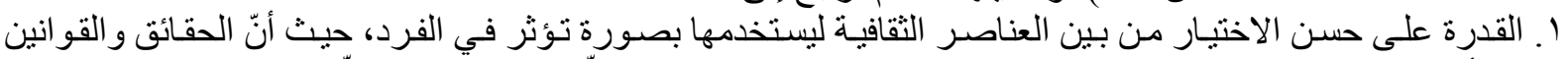

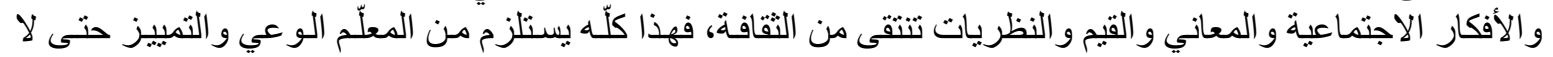
بعطي للطلاب المفاهيم الخاطنئة. r. تعطي معلومات عن البيئة التي يعيش فئها، و وعن العالم المحيط به.

ـ الإعداد العملي: ويقصد بها بدء انخر اط الطالب المعلّم في تدريب ميداني حي، على مهنة التعليم في المدارس، بمـا تنطوي

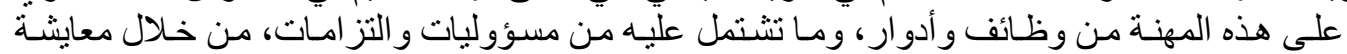

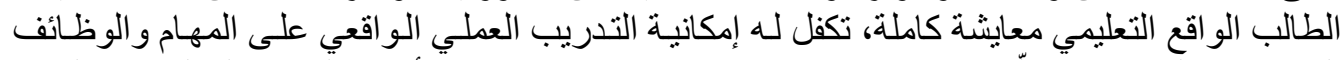

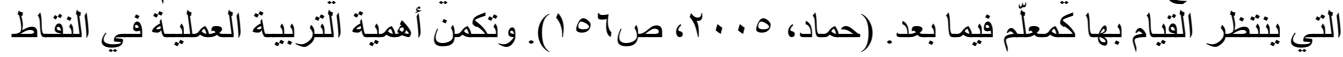

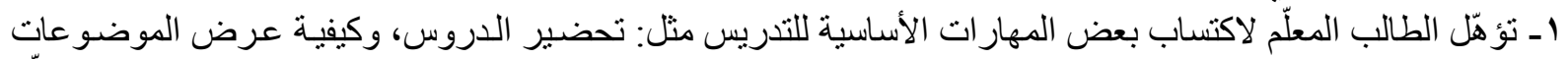

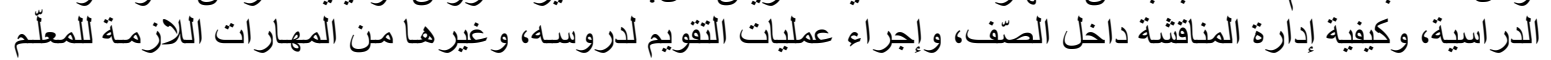

ץ ـ تعرّض الطالب المعلّم لتغيرات في سماته الشخصية، حيث يتحوّل خـلال فترة قصيرة من دور الطالب إلى دور المعلم

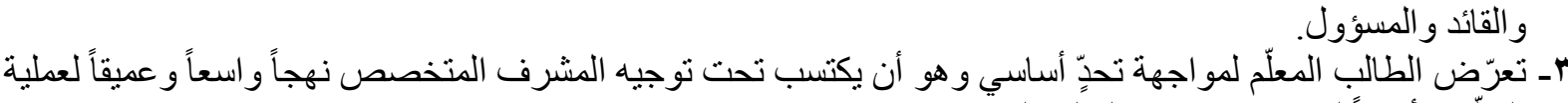

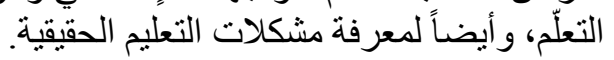

$$
\text { • } 1 \text { ـ إجراعات الداسة الداسة }
$$

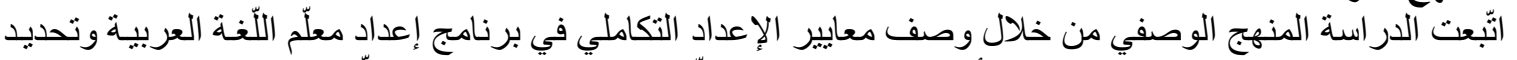

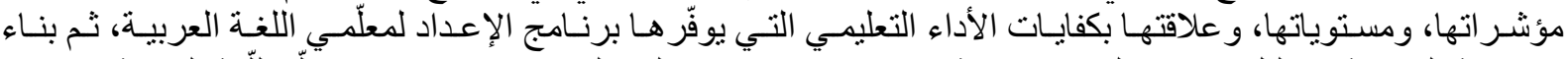

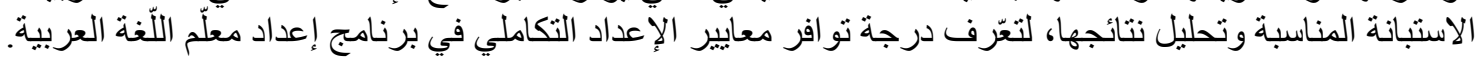

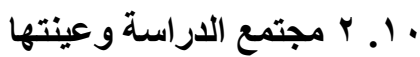

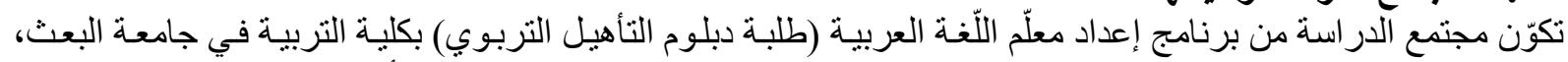

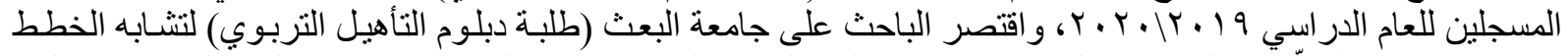

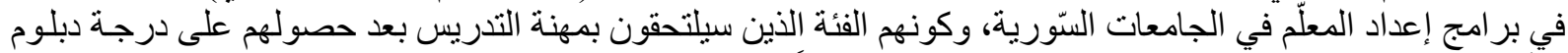

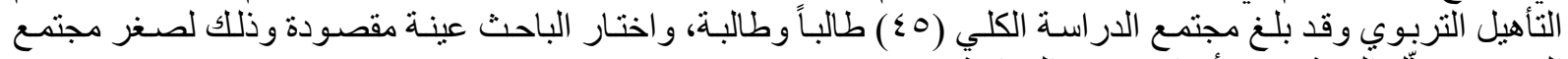

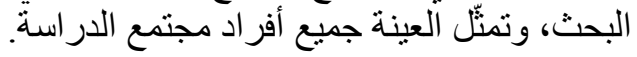

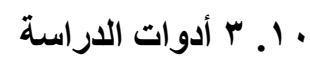

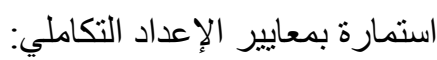

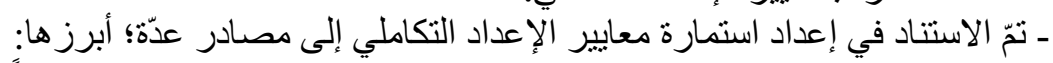

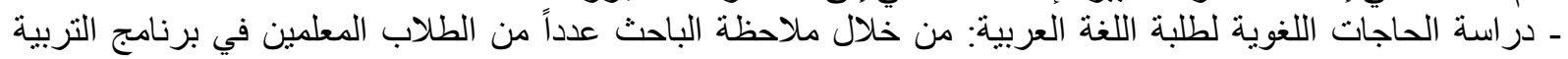

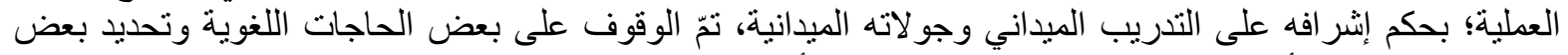

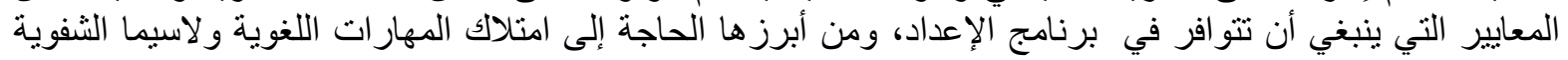


منها، و القدرة على استخدام اللغة العربية في التدريس، والتّكن من بعض كفايات تدريس المهارات اللغوية تخطيطاً و وتنفيذاً وتقويماً. .

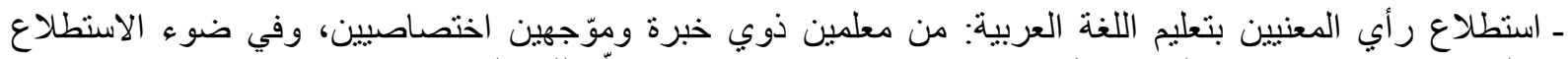

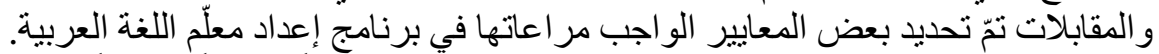

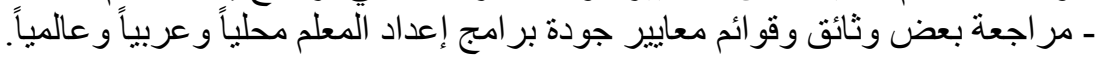
ـ مر اجعة بعض الدر اسات و البحوث السابقة، التي بحثت في معايير جودة إعداد المعلم قبل المبل الخدمة وفي أثناءها.

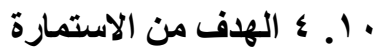

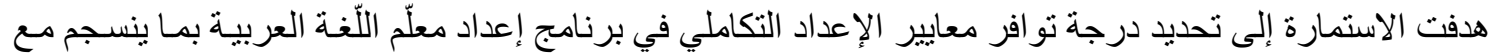

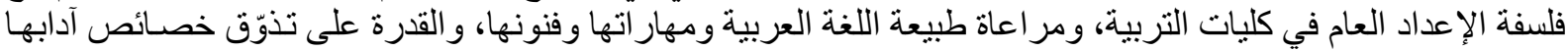
و عصور ها، و التعمّق في الدر اسات النحوية وتوظيفها في علوم العربية.

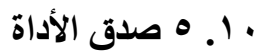

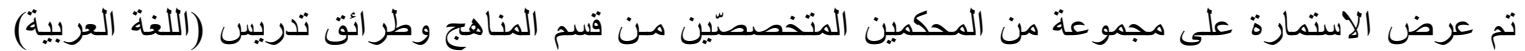

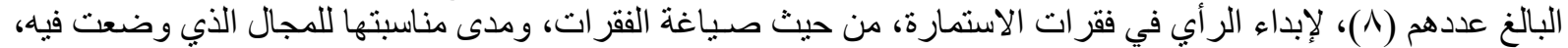

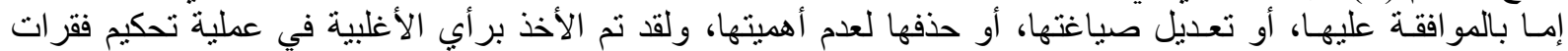

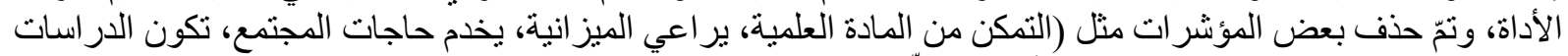

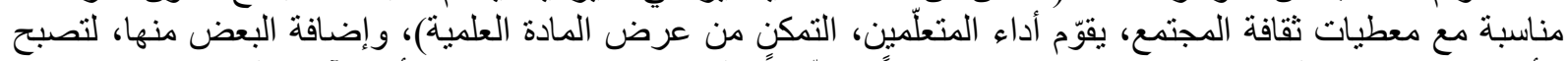

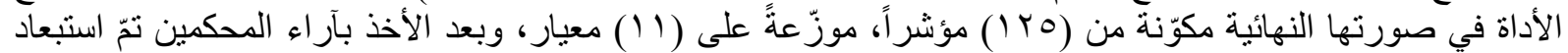

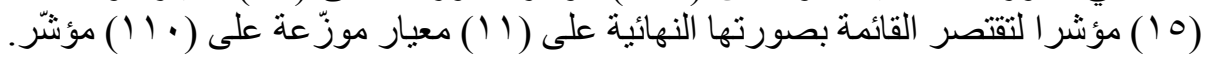

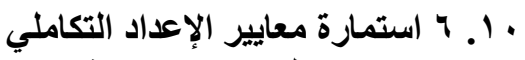

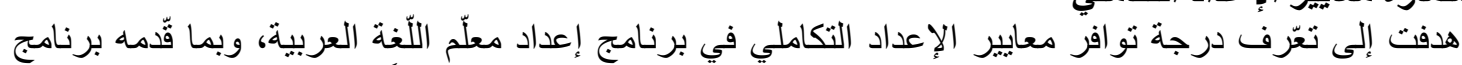

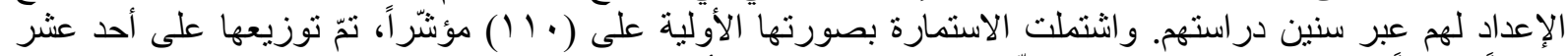

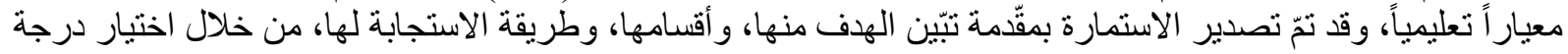

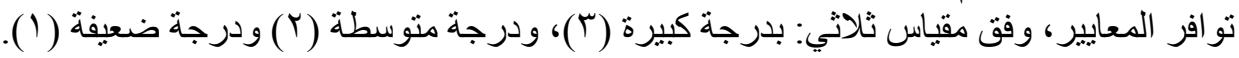

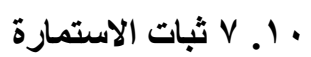

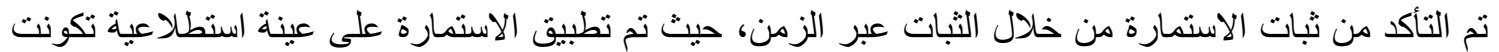

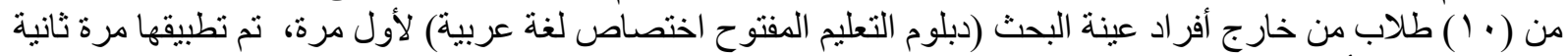

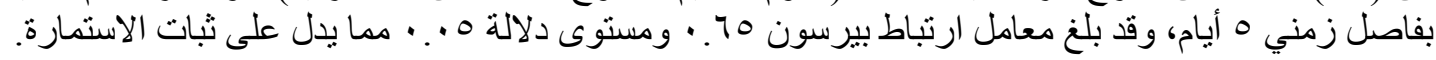

\section{1 أنطبيق أداة الدراسة والمعالجة الإحصائية}

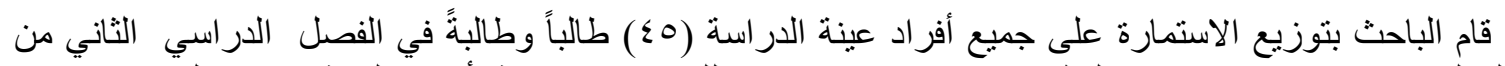

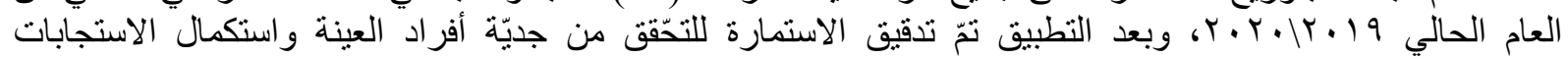

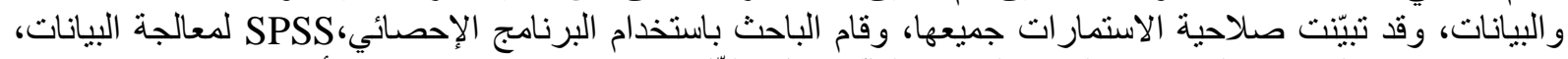

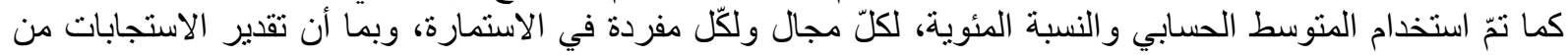
النوع الثلاثي تمّ اعتماد النسب المئوية الآتية في تقفير النتائج:

\section{جدول رقم ( (1) يوضح معيار الحكم على مدى توافر معايير الإعداد التكاملي}

\begin{tabular}{|c|c|}
\hline درجة التوافر & مدى النسبة المئوية \\
\hline كبيرة & 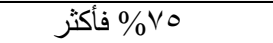 \\
\hline متوسطة & من · \% \% إلى ع \% \\
\hline ضعبفة & أقل من • •\% \\
\hline
\end{tabular}

ب ا م التائج الدر اسة وتفسير ها

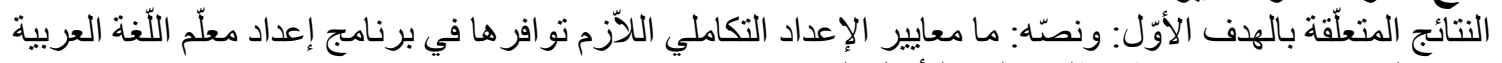

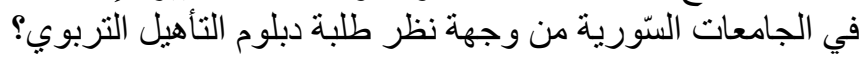




\begin{tabular}{|c|c|c|c|}
\hline 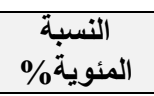 & المؤشرات & العبارات & معاييز الإعداد التكاملي \\
\hline$\%$ \%r, Trq & rq & $r z_{-1}$ & 1- الربط بين المقدرة الأغوية و المهنية. \\
\hline$\% 0, \leqslant 0$ & 7 & rrorV & r - - يكتسب السّمات و الخصائص المهنية تكاملياً. \\
\hline$\%$ & V & $r q-r r$ & r- - التكامل بين المعارف الأساسية للتدريس الفعّال وتوظيفها. \\
\hline$\% \wedge, 1 \wedge$ & 9 & $\varepsilon \wedge-\varepsilon \cdot$ & ع - تحقيق التكامل بين المعرفة التخصنصية وطر ائق تدريسها. \\
\hline$\%$ IY,VYV & $1 \varepsilon$ & TY- $\{9$ & هـ تحقيق التكامل بين جوانب الإعداد التخصصني ومهار ات البحث العلمي و التربوي \\
\hline$\% 0, \leqslant 0$ & 7 & งก_t4 & آ- تحقيق التكامل بين المكوّنات الثلاثة لبرنامج إعداد المعلُم" الإعداد التخصصي، و المهني، \\
\hline$\% \mathrm{o}, \mathrm{rV}$ & $\Lambda$ & VI.79 & V- ت تحقيق الربط بين طر ائق التدريس وما يستجد من وسائط وتقنيات. \\
\hline$\% \vee, r V$ & $\Lambda$ & $\Lambda \varepsilon-V V$ & 1-ـ تحقيق التكامل بين المعرفة التخصتصبية والتطبيق العملي. \\
\hline 1. & 11 & $9 \theta_{-} \wedge \theta$ & 9 9- يجعل تقويم الطالب المعلْم تكاملياً: \\
\hline$\% \wedge, 1 \wedge$ & 9 & $1 \cdot \varepsilon-97$ & • 1- تكامل المهار ات المهنية عند تعليم اللغة العربية. \\
\hline$\% 0, \leqslant 0$ & 9 & $11 \cdot-1 \cdot 0$ & ا I- يربط الإعداد الثقافي للطالب المعلُم اللغة ببعدها الثقافي و الاجتماعي. \\
\hline$\% 1 \cdots$ & 11. & & المجموع الكلي: \\
\hline
\end{tabular}

ا. الجدول رقم (Y) يوضح معايير الإعداد التكاملي في برنامج إعداد معلّم اللغة العربية، ومؤشر اتها، ونسب توزّع كل منها في القائمة.

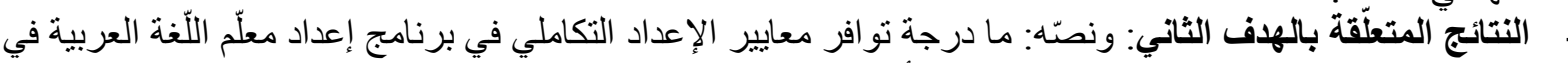

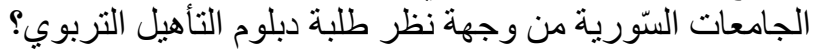

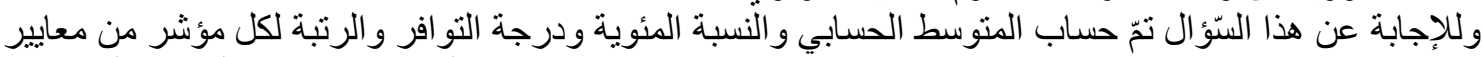

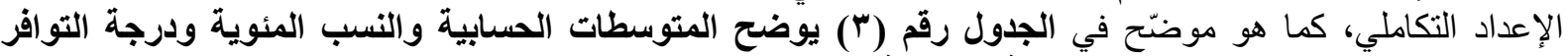
والترتيب لمعيار (الربط بين المقلرة اللفوية والمهنية)

\begin{tabular}{|c|c|c|c|c|c|}
\hline 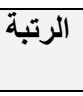 & 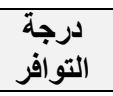 & 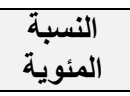 & المستوسط & الربط بين المقدرة اللغوية والمهنية & 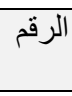 \\
\hline T & متوسطة & $\% 7 V$ & $r, \cdot 1$ & القدرة على تطبيق القو اعد الوظيفية في اللغة العربية. & $1-1$ \\
\hline Tr & ضتعيفة & $\% \leqslant 1,77$ & $1, Y_{O}$ & القدرة على إعداد البحوث التربوية و أصول تدوينها. & $\begin{array}{l}1-1 \\
\end{array}$ \\
\hline r7 & ضعيفة & $\%$ \%^ & $1,1 \leq$ & القدرة على تطبيق القو اعد الإملائية في اللغة العربية. & $1-4$ \\
\hline$r \cdot$ & ضعيفة & $\% \leqslant 0$ & $1, r_{0}$ & القدرة على ربط اللغة العربية بعلوم القَر آن الكريم. & $1-\varepsilon$ \\
\hline Tr & ضعيفة & $\% \leqslant r$ & $1, Y 4$ & القدرة على ربط اللغة العربية بعلوم الحديث. & $1-0$ \\
\hline 7 & متوسطة & $\% 09$ & $1, \mathrm{VV}$ & القدرة على تذوّق الأدب في العصر الجاهلي. & $1-7$ \\
\hline $\mathrm{V}$ & متوسطة & $\% 0 \wedge, \mu r$ & 1,10 & القدرة على تذوّق الأدب في العصر الإسلامي. & $1-V$ \\
\hline Tr & متوسطة & $\% 07$ & 1,71 & القدرة على تذوّق الأدب في العصر الأموي. & $1-1$ \\
\hline 0 & متوسطة & $\% 09, r \mu$ & 1,199 & القدرة على تذوّق الأدب في العصر العباسي. & $1-9$ \\
\hline $1 \varepsilon$ & 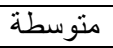 & $\% 00$ & 1,70 & القدرة على تذوّق الأدب في العصر الأندلسي. & $1-1 \cdot$ \\
\hline$\Lambda$ & متوسطة & $\%$ \% , r & $1, V r$ & القدرة على تذوّق الأدب في العصر المملوكي. & $1-11$ \\
\hline r & متوسطة & $\% 71,77$ & 1,10 & بحوثة. على البحث في مصادر التراث العربي وطرق التعامل معها للإفادة منها في & $1-14$ \\
\hline Tร & ضعيفة & $\% \varepsilon \cdot, 77$ & $1, Y Y$ & القدرة على تطبيّق القو اعد العروضية في نصوص اللغة العربية. & $1-14$ \\
\hline IV & ضعيفة & $\% \leqslant \Lambda, 77$ & $1, \leqslant \wedge$ & القدرة على المقارنة بين المدارس الأدبيةً العربية و الغربية. & $1-1 \leqslant$ \\
\hline 1 & كبيرة & $\% \vee 7,77$ & $r, r$ & القدرة على التمييز بين تنظيمات المناهج ومكوّناته و أهميته في المنظومة التعليمية & $1-10$ \\
\hline$\varepsilon$ & متوسطة & $\% 09,77$ & $1,1,9$ & 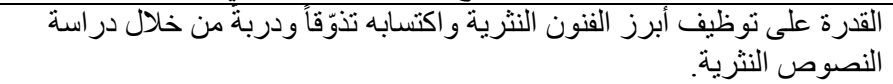 & 1.17 \\
\hline 17 & ضنعيفة & $\% \leq 9,77$ & $1, \leqslant 9$ & القدرة على توظيف الدر اسات النحوية في اللغة العربية. & $1-1 V$ \\
\hline 19 & ضعيفة & $\varepsilon\rceil, \mu$ & $1, r 9$ & القدرة على توظيف المناهج النقدية و استخدامها. & $1-11$ \\
\hline 11 & ضعيفة & $\% \leqslant \Lambda$ & $1, \leqslant \varepsilon$ & القصدة على توظيف قضايا الثّعر العربي الحديث و اتجاهاته ومدارسه في در اسة & $1-19$ \\
\hline 14 & منوسطة & $\% 00, r$ & 1,77 & القدرة على تحليل نظريات علم النفس التربوي وتطبيقاته في العملية التعليمية. & $1-r \cdot$ \\
\hline 11 & متوسطة & $\% 07, \mu$ & 1,79 & القدرة على توظيف نظريات علم نفس النمو في العملية التعليمية. & $1-T_{1}$ \\
\hline $1 \cdot$ & متوسطة & $\% 07,77$ & $1, \mathrm{~V} \cdot$ & القدرة على توظيف الأجهزة الحديثة وتقنياتها في ميدان العملية التعليمية. & I-YY \\
\hline ro & ضنعيفة & $\%$ \%q & $1,1 \mathrm{~V}$ & القدرة على كيفية إدارة الأزمات التربوية و اقتر اح الحلول المناسبة لها. & $1-r r$ \\
\hline Y1 & ضنعيفة & $\% \leqslant \Sigma, \mu$ & $1, \mu$ & القدرة على استخدام تقنيات التعبير الثفوي في التو اصل و التفسير . . & $1-r \leqslant$ \\
\hline 9 & متوسطة & $\% \circ \mathrm{V}$ & 1,1 & القدرة على تصميم الاختبار ات العملية وأسس تقويمها. & $1-10$ \\
\hline 10 & متوسطة & $\% 0 \cdot 77$ & $1,0 Y$ & القدرة على التمبيز بين نظريات التعلُم و العو امل التي تؤثر في التعلَّم. & $1-r 4$ \\
\hline
\end{tabular}




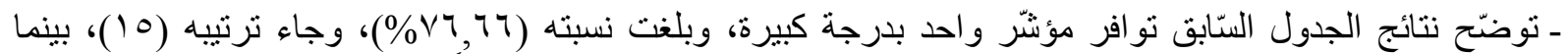

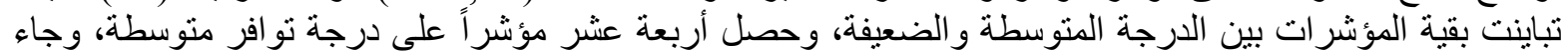

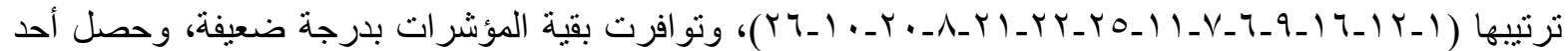

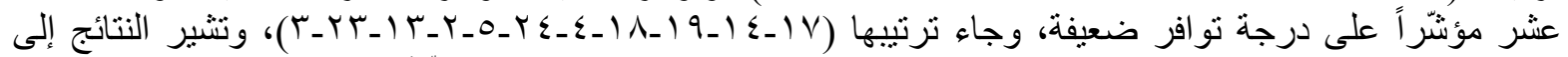

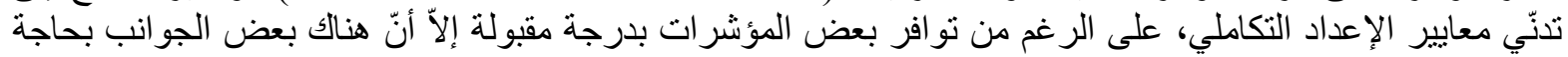

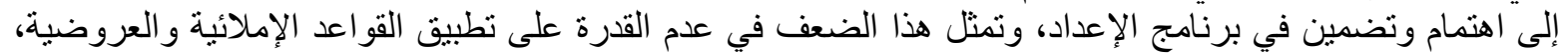

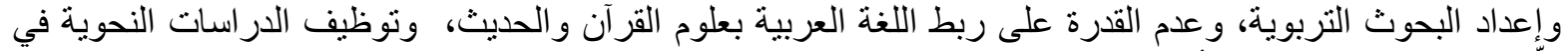

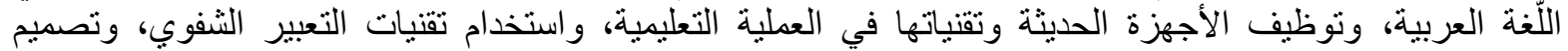

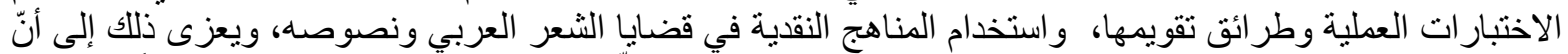

برنامج الإعداد يركز على المعرفة النظرية دون الإلمام بقدرات الطالب اللّنوية، ونوظيف مهار اته المهنية عملياً.

r- جدول رقم (ع) يوضح المتوسطات الحسابية والنسب المئوية ودرجة التوافّر والترتيب لمعيار (اكتساب السّمات

والخصائص المهنية تكاملياً):

\begin{tabular}{|c|c|c|c|c|c|}
\hline الرتبة & درجة التو افر & النسبة المئوية & المتوسط الحسابي & اكتساب الستمات والخصائص المهنية تكاملياً & T \\
\hline 1 & كبيرة & $\% 91,77$ & r, vo & القدرة على تخطيط الدروس و إعداد مستلزماتها. & T-1 \\
\hline$\varepsilon$ & كبيرة & $\% \vee \neg, r \mu$ & $r, r$ & القدرة على إدارة الصف و المحافظة على نظام المدرسة. & T-t \\
\hline r & كبيرة & $\%$ \% & $r, 0$ & تعرّف ميول وحاجات المتعُلَمين. & T-T \\
\hline r & كبيرة & $\%^{\vee \wedge}$ & $T, \Gamma \varepsilon$ & الققرة على البحث و الاستطلاع. & $T-\xi$ \\
\hline 7 & متوسطة & $\%^{v}$. & r, & التمكّن من استخذام وتصميم الوسائط التعليمية. & T-O \\
\hline 0 & كبيرة & $\% \vee 0,74$ & $\overline{T, Y V}$ & تتمتّع بالكفاءة في استخذام أساليب التثقيم. & T-T \\
\hline
\end{tabular}

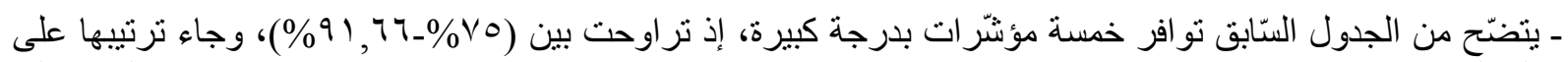

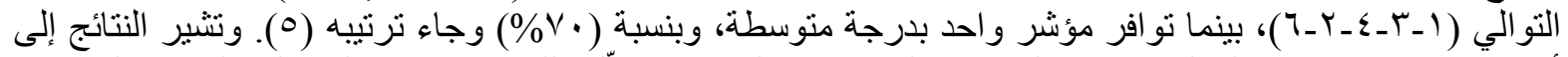

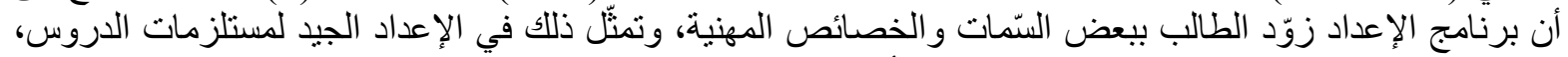

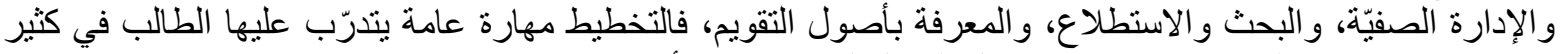
من جو انب الإعداد، التي تعتبر مفتاح نجاح العملية التعليمية وتحقيق أهدافها.

r- جدول رقم (ه) يوضح المتوسطات الحسابية والنسب المئوية ودرجة التوافر والترتيب لمعيار (التكامل بين المعارف الأساسية للتدريس (الفقّال وتوظيفها):

\begin{tabular}{|c|c|c|c|c|c|}
\hline 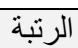 & درجة التو افر & النسبة المئوية & المتوسط الحسابي & التكامل بين المعارف الأساسية للتدريس الفعّال وتوظيفها & $r$ \\
\hline r & كبيرة & $\% \vee 0,77$ & r, rV & تعرّف مفهوم التدريس ومهار اته. & $r-1$ \\
\hline$\varepsilon$ & متوسطة & $\% 07,77$ & $1, \mathrm{~V}$ & تحدد طر ائق التدريس التقليدية. & $r-4$ \\
\hline 0 & متوسطة & \%०R, & 1,7 & تحدد أبرز الاستر اتيجيات الحديثة في تنمية التفكير. & $r-r$ \\
\hline V & ضعيفة & $\% \leq 0$ & $1, r_{0}$ & تعرّف مداخل التدريس. & r-乏 \\
\hline r & متوسطة & $\% 70$ & 1,90 & تطبّق مهار ات التخطيط اليومي للمو اد الدر اسية. & $r-0$ \\
\hline 1 & كبيرة & $\% \vee 7,77$ & $r, r$ & تطبّق المهار ات اللازمة لممارسة الأدوار المنوقعة منه. & $r-7$ \\
\hline 7 & ضعيفة & $\% \leq 7,77$ & $1, \varepsilon$ & تطبّق استر اتيجيات التقويم الحديثة للمهار ات التعليمية بأنو اعها. & $r-v$ \\
\hline
\end{tabular}

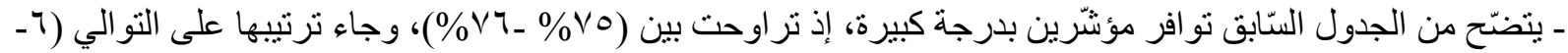

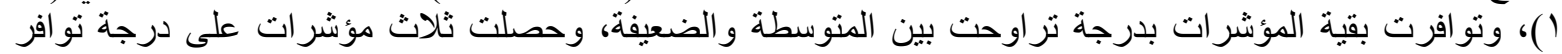

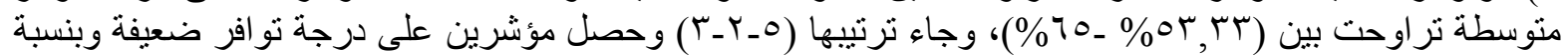

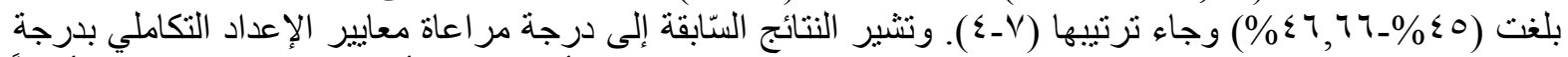

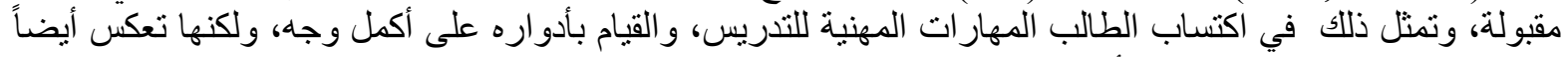

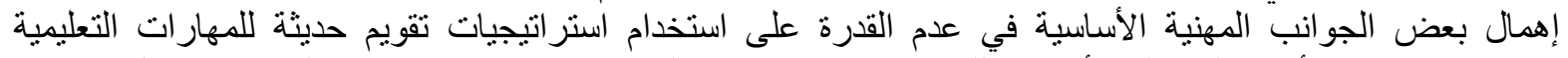

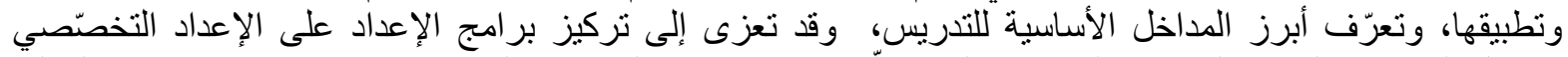
و إغفال المهار ات المهنية الخاصة بالتدريس، التي تتعلّق بكيفية تطبيق المهار التئ المهنية تخطيط وتنفيذ وتقويم في العملية الإنية 
ـ - جدول رقم (7) يوضح المتوسطات الحسابية والنسب المئوية ودرجة التوافر والترتيب لمعيار (تحقيق التكامل بين المعرفة التخصصية وطر ائق تلدريسها):

\begin{tabular}{|c|c|c|c|c|c|}
\hline الرتبة & درجة التوافر & النسبة المئوية & 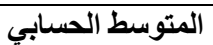 & تحقيق التكامل بين المعرفة التخصصية وطرائق تدريسها & $\xi$ \\
\hline $\mathrm{v}$ & ضعيفة & $\% \leqslant \Lambda, r r$ & 1,20 & القدرة على تدريس مهار ات الاستماع وكفاياته. & $\varepsilon-1$ \\
\hline 1 & منوسطة & $\% \uparrow \lambda, r \mu$ & $T, \cdot 0$ & القدرة على تدريس مهار ات القراءة وكفاياتها. & $\varepsilon-1$ \\
\hline$\Gamma$ & متوسطة & $\% 09$ & $1, V \mathrm{~V}$ & القدرة على تدريس مهارات الكتابة وكفاياتها. & $\varepsilon_{-} \Gamma$ \\
\hline 7 & ضعيفة & $\% \leqslant 9,77$ & $1, \leqslant 9$ & القدرة على تدريس مهار ات التعبير الثفوي وكفاياته. & $\varepsilon-\varepsilon$ \\
\hline 9 & ضعيفة & $\% \leqslant 0$ & $1, r_{0}$ & القدرة على تدريس مهار ات البلاغة وكفاياتها. & $\varepsilon_{-} 0$ \\
\hline o & متوسطة & $\% 0 \leqslant$ & $1, \pi$ & القدرة على تدريس مهارات النحو العربي وكفاياته. & $\varepsilon_{-} T$ \\
\hline$\varepsilon$ & متوسطة & $\% 07,77$ & $1, \mathrm{~V}$ & القدرة على تدريس مهار ات الإملاء و كفاياته. & $\varepsilon-\gamma$ \\
\hline$\Lambda$ & ضعيفة & $\% \leqslant 7,77$ & $1, \xi$ & القدرة على تدريس مهار ات الخط العربي وكفاياته. & $\varepsilon_{-} \Lambda$ \\
\hline r & متوسطة & $\% 74,74$ & r & 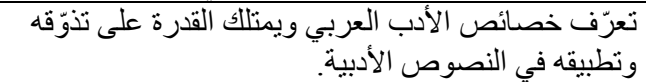 & $\varepsilon-9$ \\
\hline
\end{tabular}

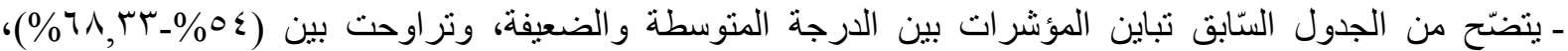

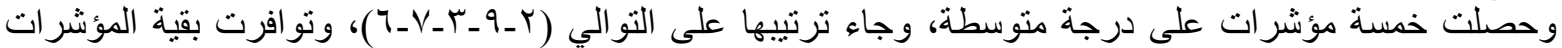

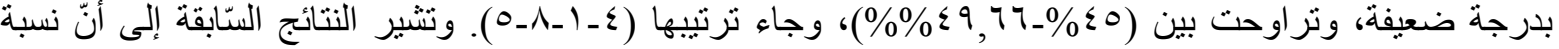

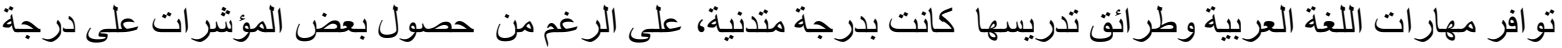

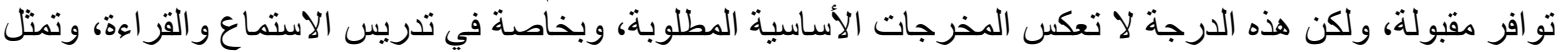

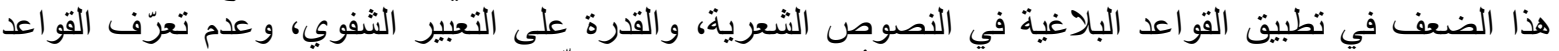

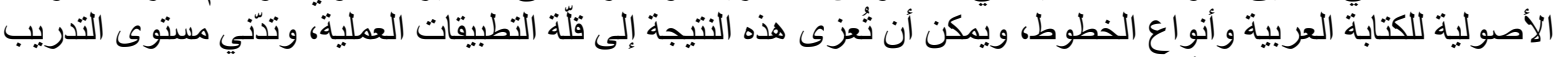

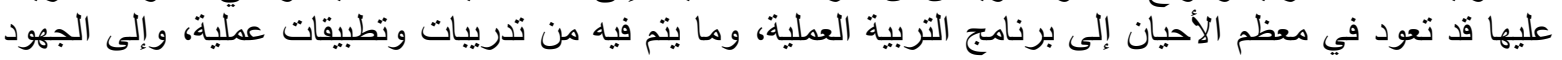

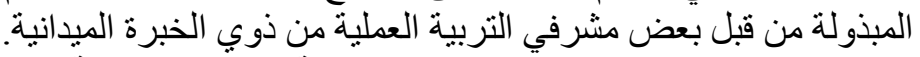

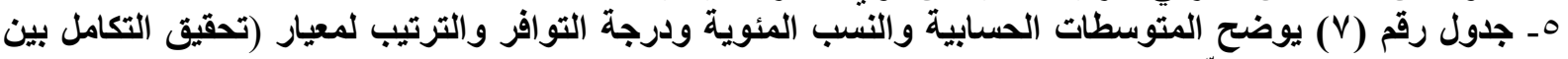
جوانب الإعداد التخصصتي ومهارات البحث العلمي والتربوي):

\begin{tabular}{|c|c|c|c|c|c|}
\hline 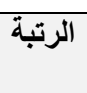 & درجة التوافر & النسبة المئوية & المتوسط الحسابي & 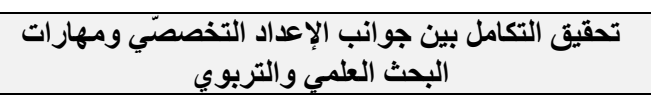 & 0 \\
\hline$r$ & متوسطة & $\% 77,77$ & $r$ & تعرّف منهج التقويم الفردي في مجال التراث العربي. & $0-1$ \\
\hline 1 & متوسطة & $\% \vee \varepsilon$ & T,YY & تفرّق بين المصدر و المرجع. . & $0_{-}{ }^{\prime}$ \\
\hline$r$ & متوسطة & 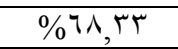 & $r, 0$ & تعرّف حركة التدورين في المكتبة العربية. & $0_{-1}$ \\
\hline$\varepsilon$ & متوسطة & $\% 09$ & $1, V V$ & تستخرج المعلومة من المصنادر بسهولة ويسر. & 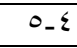 \\
\hline $\mathrm{V}$ & ضعيفة & $\% \leqslant 9,77$ & $1, \leqslant 9$ & تلمّ بطر ائق البحث و استخدام القو اميس و المعاجم العربية. & $0_{-} \mathrm{V}$ \\
\hline 9 & ضعيفة & $\% \leqslant 0$ & $1, r_{0}$ & تمنلك معرفة كافية بأنو اع المصادر اللغوية. & 0.7 \\
\hline 11 & ضعيفة & $\%$ \% , Ћ & 1,17 & تتمكّن من مهار ات استخدام المكتبة العربية. & $0-V$ \\
\hline$\Lambda$ & ضنعيفة & $\% \leqslant 0$ & $1, r_{0}$ & تعرف بعض المحققين و الاطلاع على نماذجه. & $0_{-} \wedge$ \\
\hline 7 & متوسطة & $\% 01,77$ & 1,00 & تعرف المصادر اللغوية وأنو اعها. & 0.9 \\
\hline 1. & ضعيفة & $\% \leqslant 1,77$ & $1, r_{0}$ & تمنتلكها. القدرة على تعرّف أصول تحقيق المخطوطات & 0.1 . \\
\hline 0 & متوسطة & $\%$ & 1.77 & تعرف أنو اع المناهج الأدبية و النقدية و النحوية. & 0.11 \\
\hline 14 & ضعيفة & $\%$ \%q & $1,1 \mathrm{~V}$ & تعرّف أنواع البحوثٌ التربوية. & $0-11$ \\
\hline $1 \varepsilon$ & ضنعيفة & $\% r v, r r$ & $1,1 Y$ & المعرفي والمهاري. مهارات البحث اللغوي بما يخدم تكوينه & 0.14 \\
\hline IT & ضنعيفة & $\%$ \% & 1,11 & تعرّف المفاهيم الفنيّة كالصدق و الثبات الثبات وبعض طرائق & $0.1 \leq$ \\
\hline
\end{tabular}

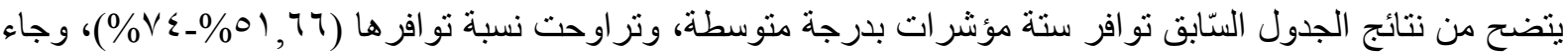

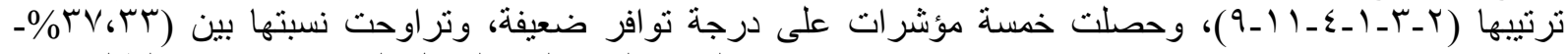

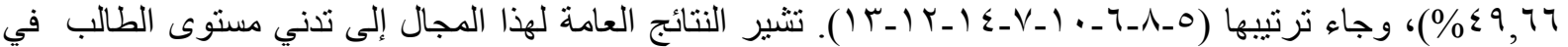

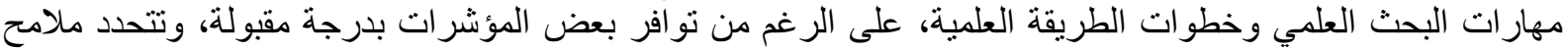

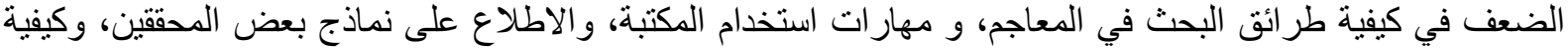


تحقيق المخطوط ونسخه، وتعرّف أنو اع البحوث التربوية، وعدم التمكن من المفاهيم الفنية كالصدق و الثبات، ويتهية ويعزى هذا

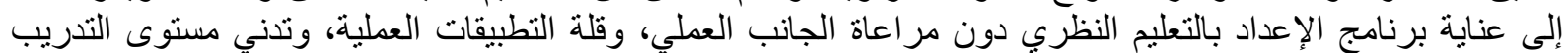

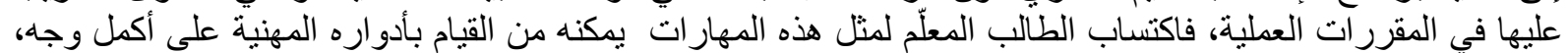
ومن ثم يوظفها في أثناء تدريسها.

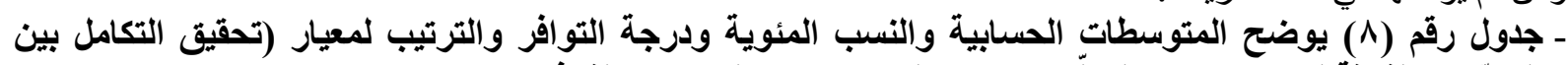
المكوّنات الثثلاثة لبرنامج إعداد المعلّم" الإعداد التخصصي، والنصب والمهني، ودرجة والثقافي):

\begin{tabular}{|c|c|c|c|c|c|}
\hline 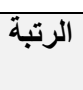 & درجة التوافر & النسبة المئوية & المتوسط الحسابي & 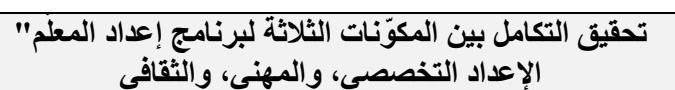 & 7 \\
\hline 0 & ضعيفة & \% & $1,1 \mathrm{r}$ & الإعداد. جو انب الإعداد الثناثة أُوز اناً تعادل أهميتها في بر امج & 7 \\
\hline$r$ & ضعيفة & $\% \leqslant 7,77$ & $1, \varepsilon$ & ير اعي التو ازن بين الخبر ات النظرية و العملية. & $T_{-1}$ \\
\hline 1 & متوسطة & $\% 70$ & 1,90 & يتضمّن المعارف و المهار ات الأساسية في المجال التخصّصي. & T-Y \\
\hline r & ضعيفة & $\% \leqslant 0$ & $1, \mu_{0}$ & يتضّمن المعارف و المهار ات في المجال المهني. . & $7-\varepsilon$ \\
\hline$\varepsilon$ & ضعيفة & $\% \leqslant 1,77$ & $1, r_{0}$ & يحوي الثقافة العامة إلى جانب المعرفة التخصيّصية. & 7.0 \\
\hline 7 & ضعيفة & $\%$ \% & 1,11 & 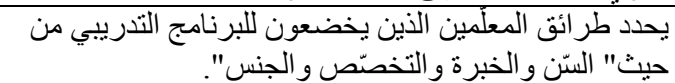 & $7-7$ \\
\hline
\end{tabular}

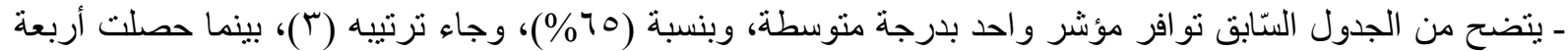

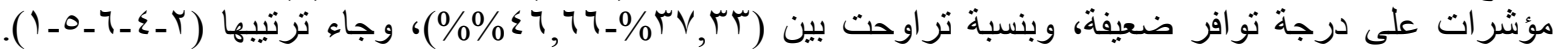

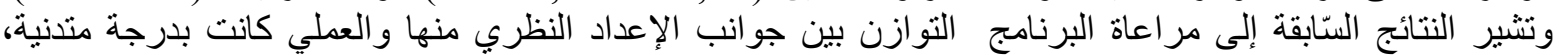

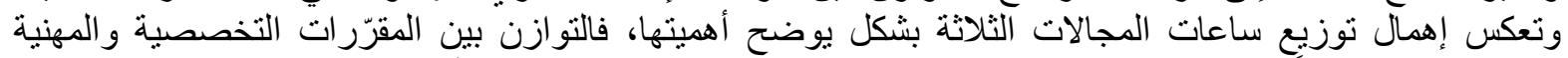

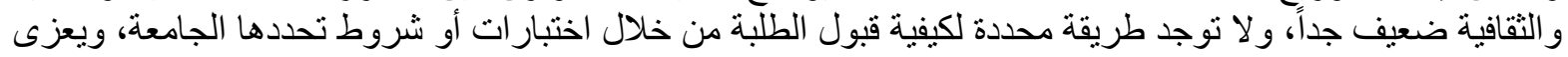

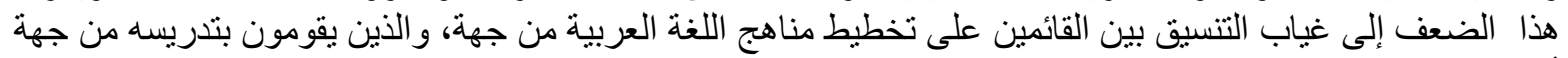

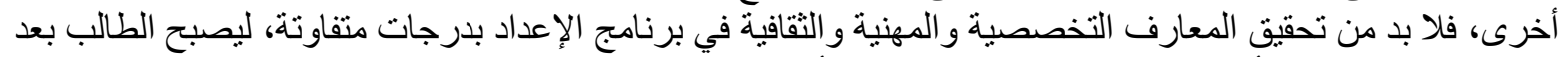

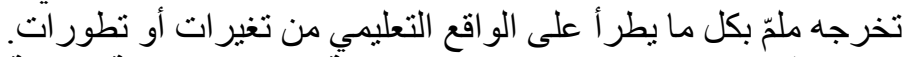
- جدول رقم (9 ) يوضح المتوسطات الحسابية والنسب المئوية ودرجة التوافر والترتيب لمعيار (تحقيق الربط بين طرائق التدريس وما يستجد من وسائط وتقنيات):

\begin{tabular}{|c|c|c|c|c|c|}
\hline 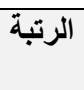 & درجة التوافر & النسبة المئوية & المتوسط الحسابي & تحقيق الربط بين طرائق التدريس وما يستجد من وسائط & V \\
\hline$r$ & متوسطة & $\% 0 \wedge, T$ & $1, \times 0$ & التعليمية. على استخدام الحاسب وبر امجه وتوظيفه في العطلية & $V_{-1}$ \\
\hline 7 & ضعيفة & $\% \leq 1,77$ & $1, r_{0}$ & وكيفية توظيفها أهمية تكنولوجيا المعلومات في العملية التعليمية & $V_{-} r$ \\
\hline 1 & متوسطة & $\% \vee \varepsilon$ & T,YY & تلمّ بالمفاهيم الأساسية لتقنيات التعليم و أسسهـ. & $V_{-}-\mu$ \\
\hline V & ضعيفة & $\% \leqslant 1$ & $1, r$ & تلمّ بمعايير تصميم الأجهزة التعليمي و أنو اعها. & $V_{-} \varepsilon$ \\
\hline 0 & ضعيفة & $\% \leqslant 0$ & $1, r_{0}$ & تعرّّف كيفية استخدام المستحدثات التكنولوجية في الأنشطة & $V_{-} 0$ \\
\hline$\Lambda$ & ضعيفة & $\% r v, r r$ & $1,1 \mathrm{~T}$ & تستخدم الأجهزة الإلكترونية الحديثة "السّبورة التفاعلية - & $\begin{array}{l}-7 \\
\end{array}$ \\
\hline$\varepsilon$ & ضعيفة & $\% \leq 7,77$ & $1, \varepsilon$ & تلمّ بمعايير تصميم الأجهزة التعليمي و أنو اعها. & $V_{-} V$ \\
\hline$r$ & متوسطة & $\% 70$ & 1,90 & 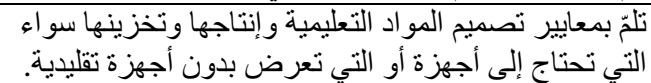 & $V_{-} \Lambda$ \\
\hline
\end{tabular}

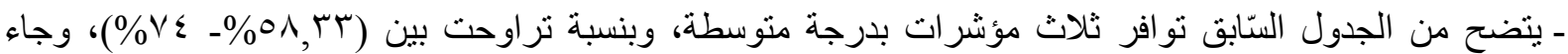

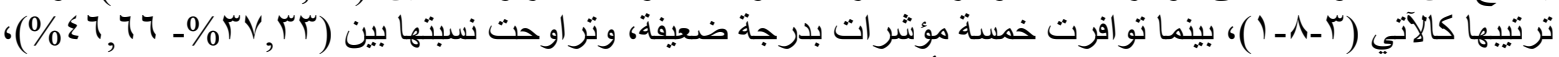

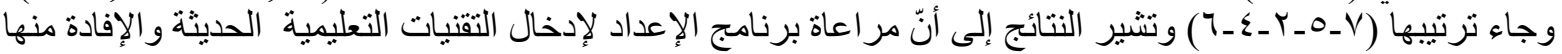

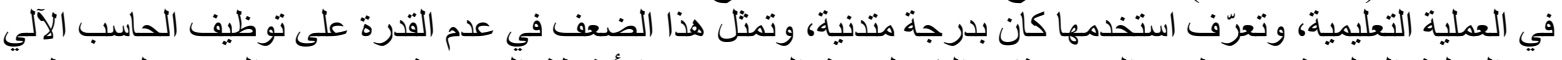

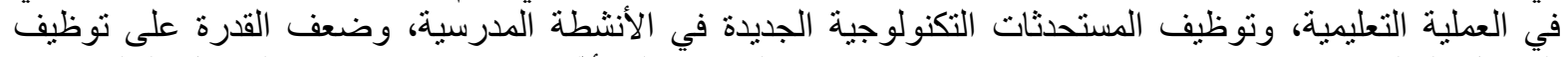

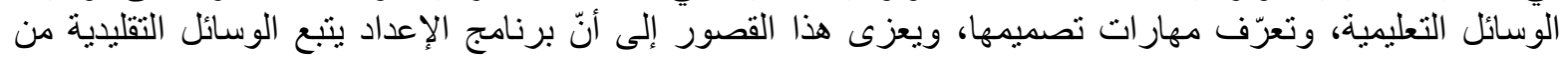


سبورة وكتاب مدرسي في أثناء عرض المادة العلمية، و عدم تدريب الطالب المعلّم على مثل هذا الوسائل التي تساعد في

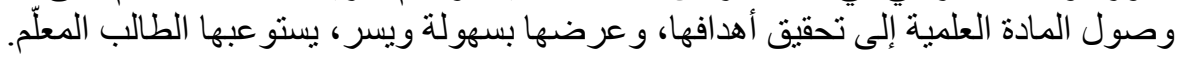

1- جدول رقم ( • 1) يوضح المتوسطات الحسابية والنسب المئوية ودرجة التوافر والترتيب لمعيار (تحقيق التكامل بين المعرفة التخصنصية والتطبيق العملي):

\begin{tabular}{|c|c|c|c|c|c|}
\hline 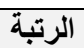 & درجة التوافز & النسبة المئوية & المتوسط الحسابي & تحقيق التكامل بين المعرفة التخصنصية والتطبيق العملي & $\Lambda$ \\
\hline 1 & كبيرة & $\%$ \%V,rr & T, r Y & التدريس. المهار ات و المعارف و الاتجاهات الأساسية لمهنة & $\Lambda_{-1}$ \\
\hline 7 & ضعيفة & $\% \leqslant 0$ & $1, \pi 0$ & تكوّن معرفة منظمة عن طبيعة التربية العملية. & $\Lambda_{-} r$ \\
\hline$\Lambda$ & ضعيفة & $\% \%^{\mu q}$ & $1,1 \mathrm{~V}$ & تعرّف العلاقة القائمة بين التربية الميدانية وبقية مكونات & $\Lambda_{-} r$ \\
\hline r & متوسطة & $\%$ & r,Tr & تطلّع أحدث الاتجاهات في استر اتيجيات التدريس. & $\Lambda_{-} \xi$ \\
\hline r & متوسطة & $\% 7 \vee, 7 T$ & $r, \cdot r$ & تمتلك المهار ات و الخبر ات و الاتجاهات الإيجابية نحو مهنة & $\Lambda_{-} 0$ \\
\hline$\varepsilon$ & متوسطة & $\% 0$. & 1,0 & 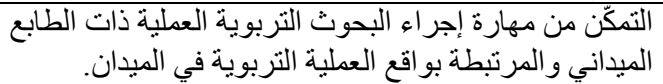 & $\Lambda_{-} 7$ \\
\hline V & ضعيفة & $\% \leqslant \varepsilon$ & $1, r$ r & بأنو اعهب الستر اتيجيات التقويم الحديثة للمهار ات التعليمية & A_V \\
\hline 0 & ضعيفة & $\% \leqslant 7,77$ & $1, \varepsilon$ & - التعليمكن من تنفيذ استر اتيجيات تعليمية جديدة في الموقف & $\Lambda_{-} \Lambda$ \\
\hline
\end{tabular}

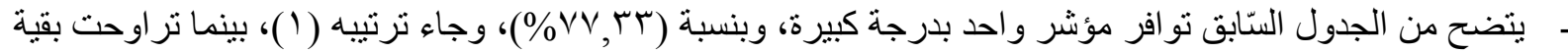

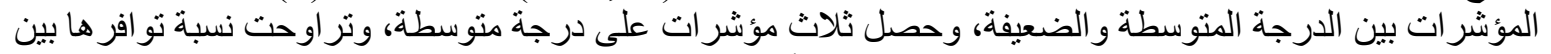

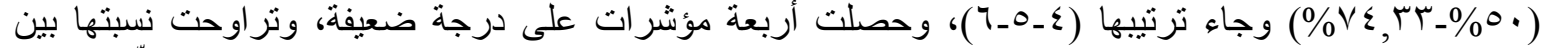

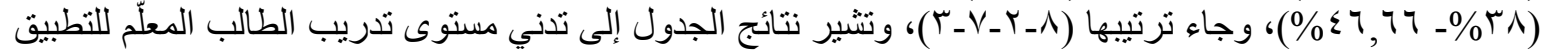

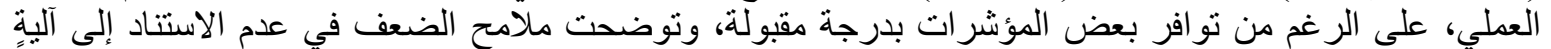

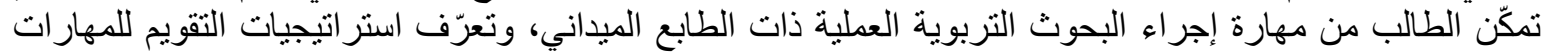

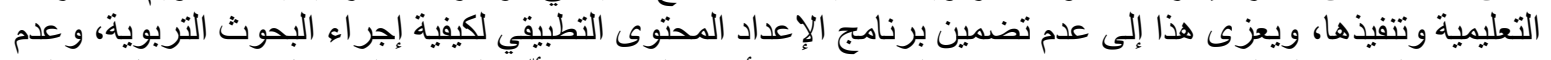

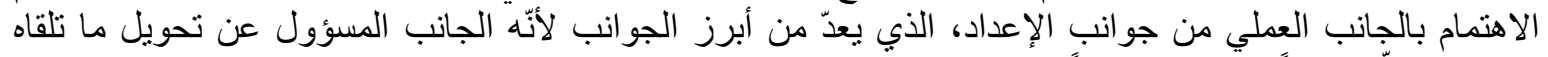

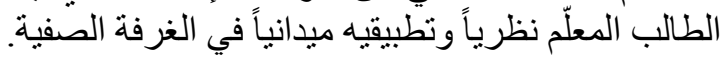
9- جذول رقم (1 1 (1) يوضح المتوسطات التحسابية والنسب المئوية ودرجة التوافر والترتيب لمعيار ( يجعل تقويم الطالب المعلم متكاملاً):

\begin{tabular}{|c|c|c|c|c|c|}
\hline الرتبة & درجة التوافر & النسبة المئوية & المتوسط الحسابي & يجعل تقويم الطالب المعلم متكاملاً & 9 \\
\hline 1 & كبيرة & $\% \vee 9$ & $r, r V$ & تالتعليميّة أهمية التقويم وموقعه في المنظومة & $9-1$ \\
\hline$\Lambda$ & ضعيفة & $\% \leq 7,77$ & $1, \varepsilon$ & تذكر أنواع ووظائف التقويم و إجر اءاته. & $9-Y$ \\
\hline 0 & ضعيفة & $\% \leqslant V$ & $1, \leqslant 1$ & أنواعمّا. نماذج للاختبارات التحصيلية بكافة & 9-4 \\
\hline $1 \cdot$ & ضعيفة & $\%$ & $1,1 \mathrm{~V}$ & تصمّم نماذج لاختبار ات المقاييس. & $9 \_\varepsilon$ \\
\hline 11 & ضعيفة & \% & $1,1 Y$ & تعرّف أبرز الأساليب الإحصائية. & 9.0 \\
\hline V & ضعيفة & $\% \leqslant V, r r$ & $1, \leqslant Y$ & تحدد أسس تقويم المناهج. & $9-7$ \\
\hline 7 & ضعيفة & $\% \leqslant \vee, 77$ & $1, \leqslant r$ & تقعرّفٍ ذاتياً اتيجيات تقويم الأداء و الكفايات & $9-1$ \\
\hline r & متوسطة & $\% \vee \cdot$ & r, 1 & تقارن بين وسائل و أدوات التقويم التربوي. & $9-1$ \\
\hline$r$ & متوسطة & \%TV,Tr & $r, \cdot r$ & التقويم التربوي. أتوجهات التربوية في مجال & 9.9 \\
\hline$\varepsilon$ & متوسطة & $\% 7$ & 1,1 & تحدد أساليب تقويم طر ائق التدريس. & $9-1$. \\
\hline 9 & ضعيفة & $\%$ \%q, r & 1,11 & تحلُل نتائج الاختبار ات التحصيلية إحصائياً. & $9-11$ \\
\hline
\end{tabular}




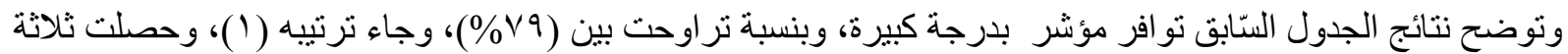

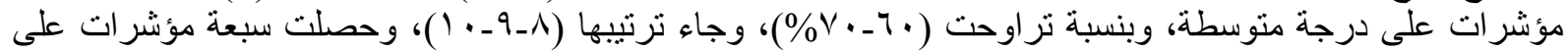

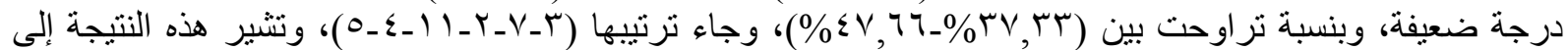

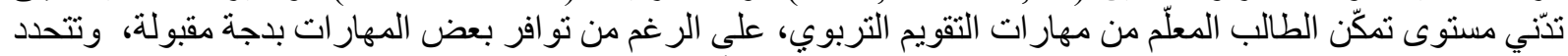

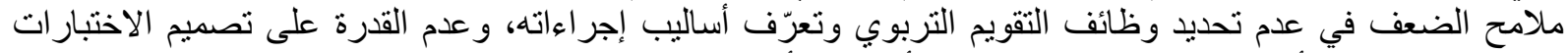

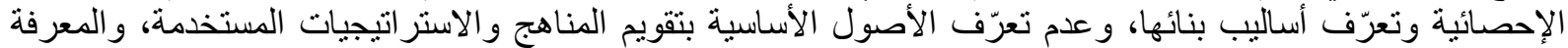

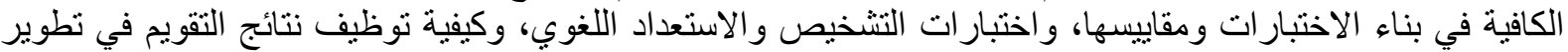

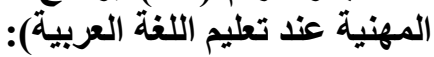

\begin{tabular}{|c|c|c|c|c|c|}
\hline 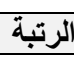 & درجة التوافر & النسبة المئوية & المتوسط الحسابي & تكامل المهارات المهنية عند تعليم اللغة العربية & 1. \\
\hline 1 & متوسطة & $\% 01$ & $1,1 \leqslant$ & تر اعي التكامل في تدريس اللغة العربية وفرو عها. & $1 \cdot-1$ \\
\hline $\bar{r}$ & متوسطة & $\% \circ r, r r$ & 1,7 & الربط بين الخبرة اللغوية بمهارات اللغة وتوظيفها. & $1 \cdot-1$ \\
\hline 7 & ضعيفة & $\% \%^{r q}$ & $1,1 \mathrm{~V}$ & تعرّف إجراءات تحقيق التكامل بين فروع التَغة العربية. & $1 \cdot-r$ \\
\hline 9 & ضعيفة & $\%$ \%V, rr & $1,1 \mathrm{r}$ & الربط بين مهارات اللغة العربية وفرو عها. & $1 \cdot-\varepsilon$ \\
\hline $\mathrm{v}$ & ضعيفة & $\% \curlyvee \wedge, 7 \uparrow$ & 1,17 & تحقيق أسس التكامل بين منهج اللغة و المو اد الأخرى. & $1 . .0$ \\
\hline$\Lambda$ & ضعيفة & $\% \uparrow \wedge$ & $1,1 \varepsilon$ & الإحاطة بالمهارات العامة و النوعية للغة العربية. & $1 \cdot-1$ \\
\hline$r$ & ضعيفة & $\% \leqslant V$ & $1, \leqslant 1$ & الإلمام بطر ائق تدريس المهارات اللغنوية وفنيّات توظيفها. & $1 \cdot-\mathrm{V}$ \\
\hline 0 & ضعيفة & $\%$ \%q, r & 1,11 & 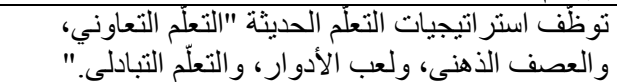 & $1 \cdot-\Lambda$ \\
\hline$\varepsilon$ & ضعيفة & $\% \leqslant 7,77$ & $1, \xi$ & وتقويم و إدارة المهارات) الأساسية التدريس (تخطيط وتنفيذ & $1 \cdot-9$ \\
\hline
\end{tabular}

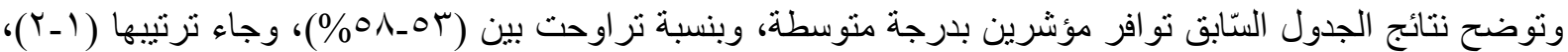

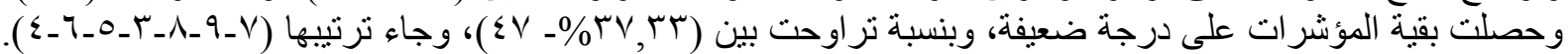

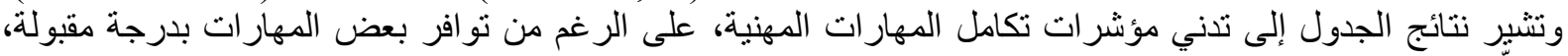

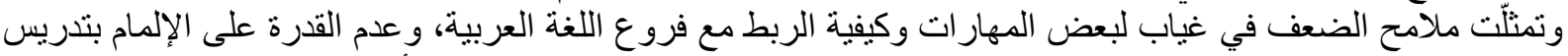

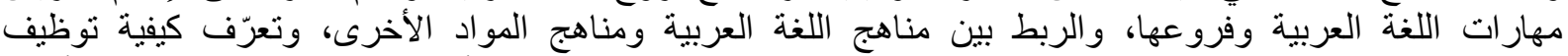

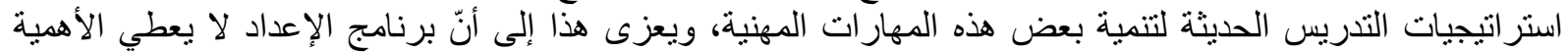

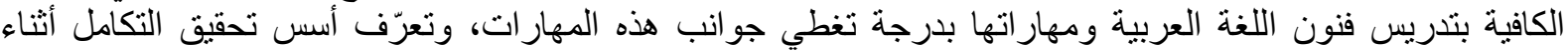

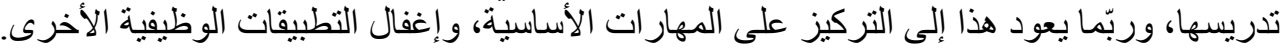

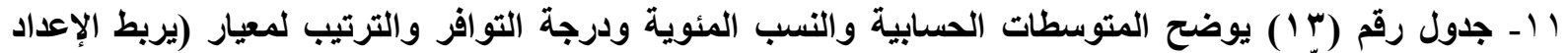
الثقافي للطالب المعلّم اللغة ببعدها الثقافي والاجتماعي):

\begin{tabular}{|c|c|c|c|c|c|}
\hline الرتبة & التوجة & النسبة النية & المستوسط المسبي & يربط الإعداد الثقافي للطالب المعلم اللغة ببعدها الثقافي & 11 \\
\hline$r$ & ضعيفة & $\% \leqslant 7,77$ & $1, \varepsilon$ & يتعرّّف مفاهيم التقافة القومية و التطور ات الحاصلة على كافة & $11-1$ \\
\hline$\varepsilon$ & ضعيفة & $\% \leq 7$ & $1, r \wedge$ & يتعرّف مفاهيم التربية المدنية و علاقتها بالعلوم الأخرى. & $11-r$ \\
\hline 0 & ضعيفة & $\% \leqslant 0$ & $1, r_{0}$ & يمتلك المهار ات التدريسية لتعلْم اللغة الأجنبية. & $11-r$ \\
\hline 1 & متوسطة & $\% 71,77$ & 1,10 & يتعرّف مفاهيم فلسفة التربية و أنو اعها و علاقتها بالعلوم الأخرى. & $11-\varepsilon$ \\
\hline r & ضعيفة & $\% \leqslant V$ & $1, \leqslant 1$ & يمتلك المهار ات التدريسية لتعلْم اللغة الفرنسية. & $11-0$ \\
\hline 7 & ضعيفة & $\% \leqslant 1$ & $1, Y T$ & يلمّ بالأصول الأساسية لثقافة مجتمعه. & 11.7 \\
\hline
\end{tabular}

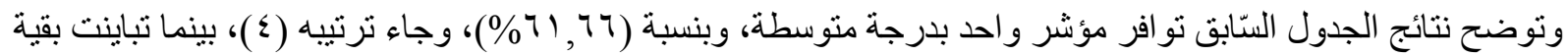

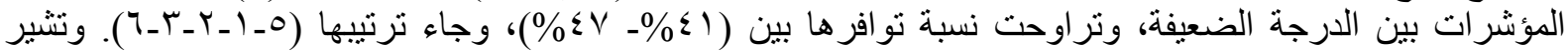

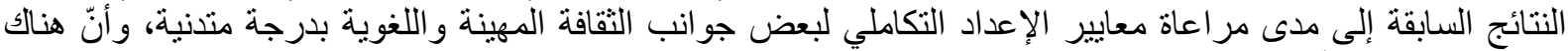

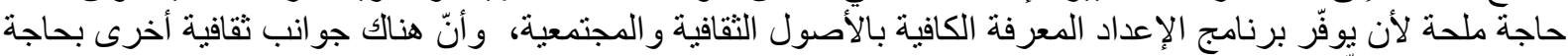
إلى تطوير، وتمثّل ذلك في تعرّف الدفاهيم الثقافية والمدنية لمجتمعه، وعلاقتهها بالعلوم الأخرى، و عدم امتلاكه مهار ات 
أساسية لتدريس اللغات الأجنبية، و إلمامه بالأصول الثقافية لثقافة مجتمعه، ويعزى ذلك إلى تركيز برنامج الإعداد على الجانب التخصصي، و وعدم مر اعاته للجو انب الثبات الثقافية منها.

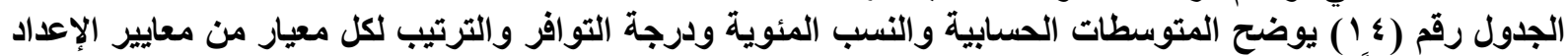

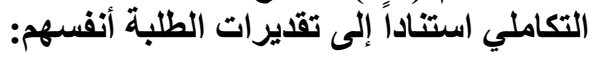

\begin{tabular}{|c|c|c|c|c|}
\hline الرتبة & درجة التوافز & النسبة المئوية & معايير الإعداد التكاملى & الرقم \\
\hline 7 & متوسطة & $\% 0 r, \pi T r$ & الربط بين المقدرة اللغوية والمهنية. & -1 \\
\hline 1 & جيدة & $\%$ Y9,17 & اكتساب الستمات و الخصائص المهنية تكاملياً. & $-r$ \\
\hline r & متوسطة & $\% 09, \wedge 0$ & التكامل بين المعارف الأساسية للتندريس الفعّال وتوظيفها. & $-\Gamma$ \\
\hline$\varepsilon$ & متوسطة & $\% 0 \leqslant, 94$ & تحقيق التكامل بين المعرفة التخصنصية وطر ائق تدريسها. & $-\varepsilon$ \\
\hline$\Lambda$ & متوسطة & $\% 0 \cdot, \mathrm{v} 01$ & تحقيق التكامل بين جوانب الإعداد التخصصتي ومهار ات البحث العلمي و التربوي. & -0 \\
\hline 1. & ضعيفة & $\% \leqslant 0, \wedge r$ & و المقيقي، التكامل بين المكوّنات الثلاثة لبرنامج إعداد المعلمّم الإعداد التخصصي، & -7 \\
\hline $\mathrm{V}$ & متوسطة & $\% 01,14$ & تحقيق الربط بين طر ائق التدريس وما يستجد من وسائط وتقنيات & -1 \\
\hline r & متوسطة & $\% 00, \sum 9 \mathrm{~V}$ & تحقيق التكامل بين المعرفة التخصنصية و النطبيق العملي. & -1 \\
\hline o & متوسطة & $\%$ OY, YAO & يجعل تقويم الطالب المعلَم متكاملاً. . & -9 \\
\hline 11 & ضعيفة & $\% \leqslant \varepsilon, 1 \leqslant 0$ & تكامل المهار ات المهنية عند تعليم اللغة العربية. & -1. \\
\hline 9 & ضعيفة & $\% \leftleftarrows \vee, \wedge \wedge \uparrow$ & يربط الإعداد الثقافي للطالب المعلُم اللغة ببعدها الثقافي و الاجتماعي. & -11 \\
\hline
\end{tabular}

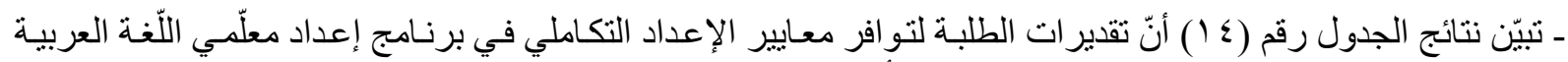

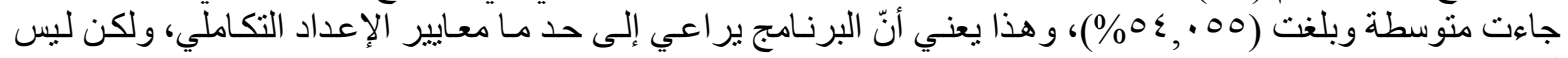

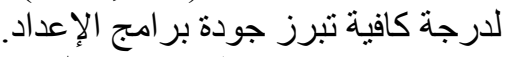

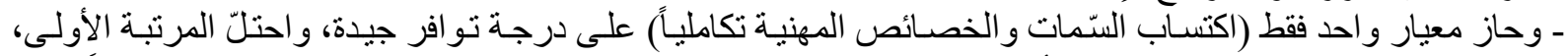

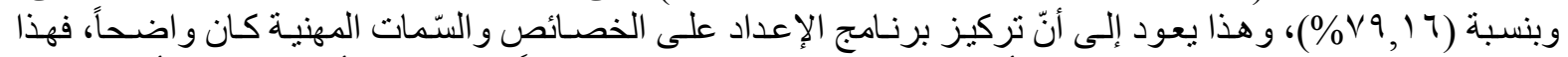

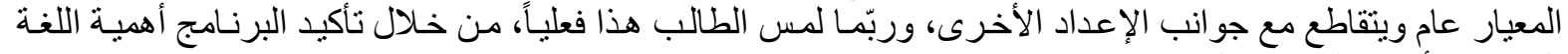
العربية، وأهية العناية بتعليمها.

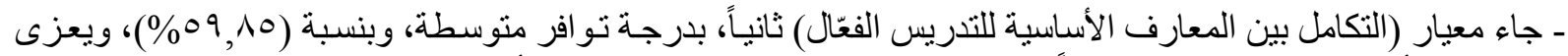

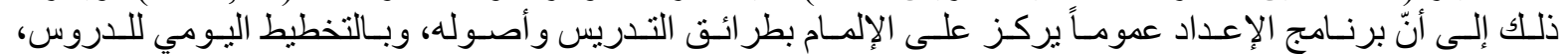

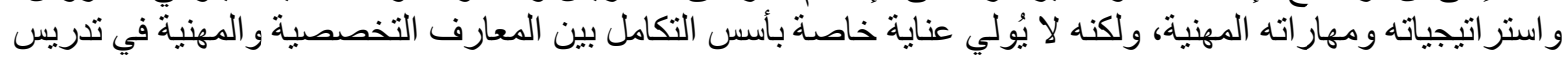
مهار مات وفروع اللغة العربية.

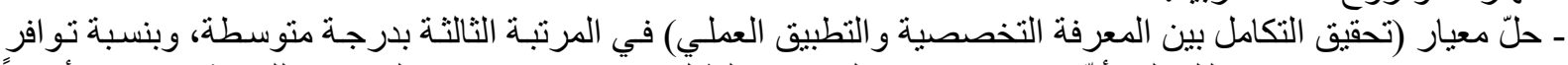

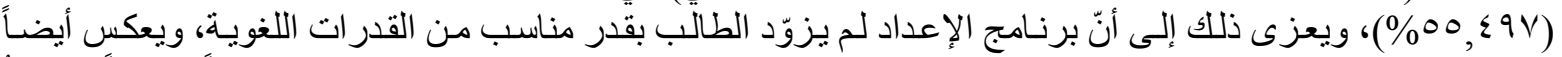

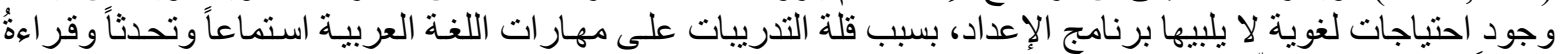

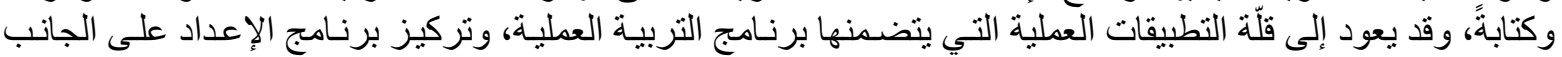
النظري أكثر من التطبيقي.

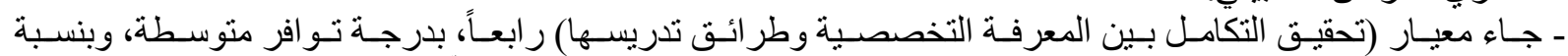

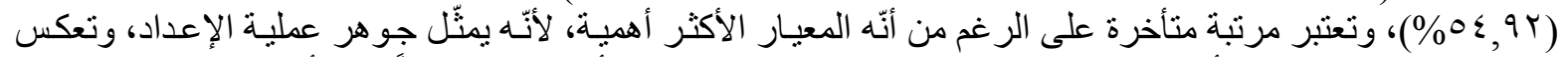

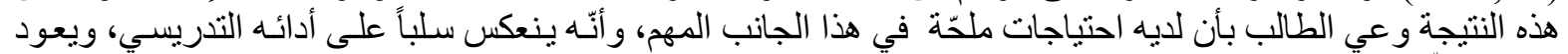

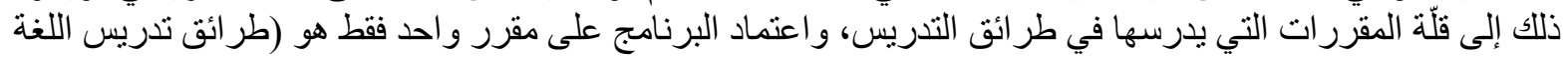

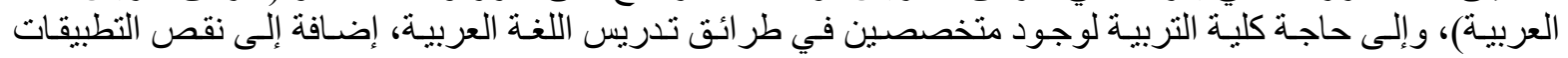

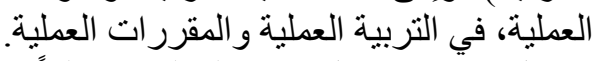

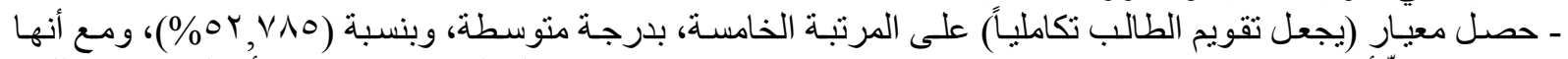

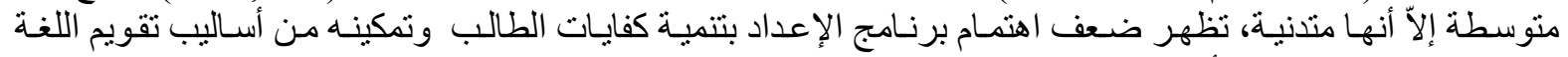

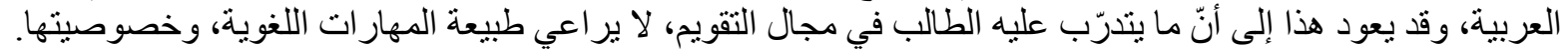

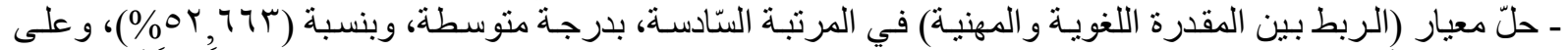

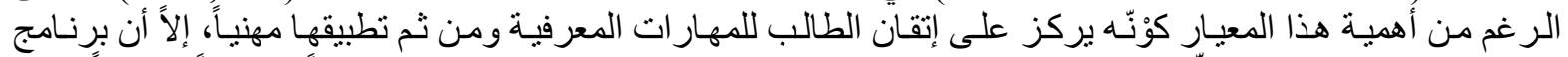

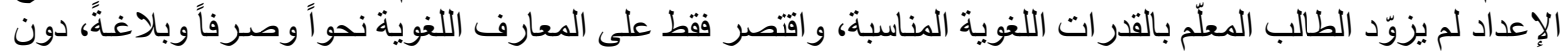

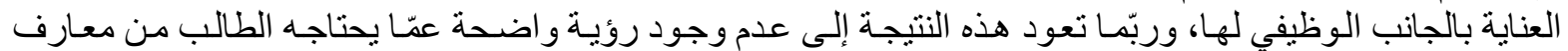




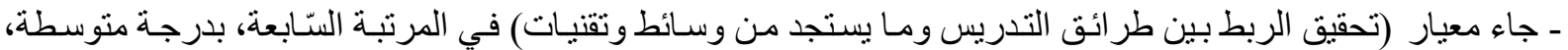

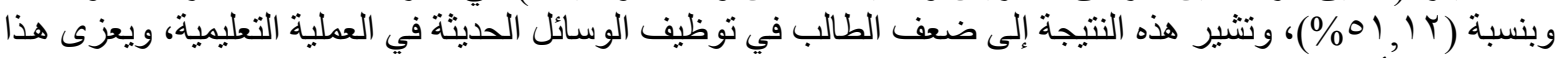

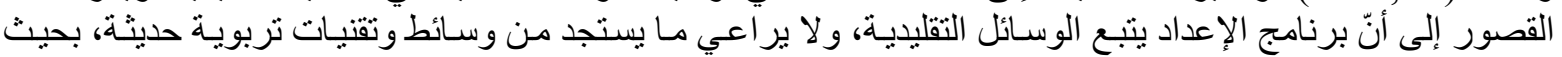

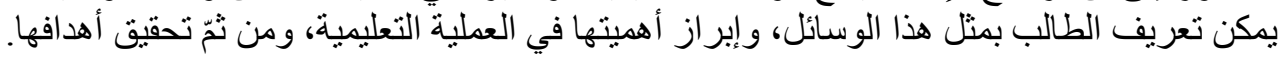

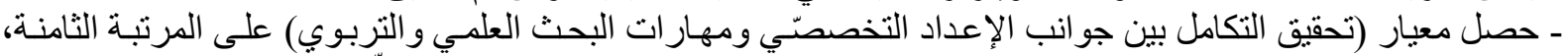

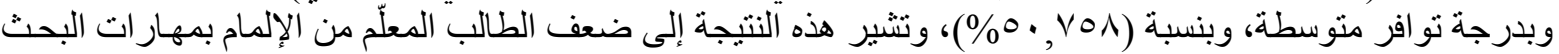

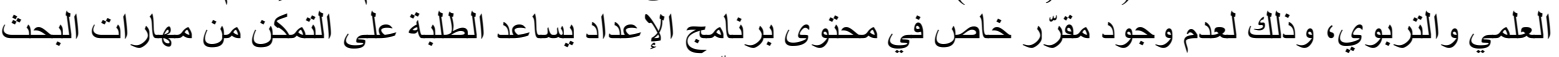

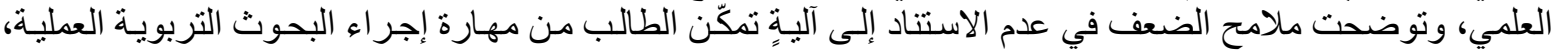

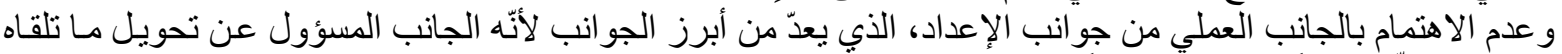
الطالب المعلّم نظرياً وتطبيقية ميدانياً في الغرفي الإنة الصفية.

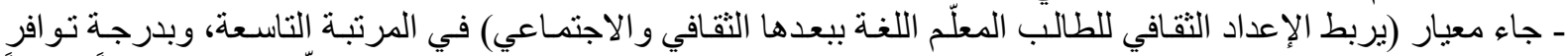

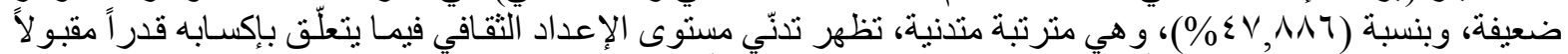

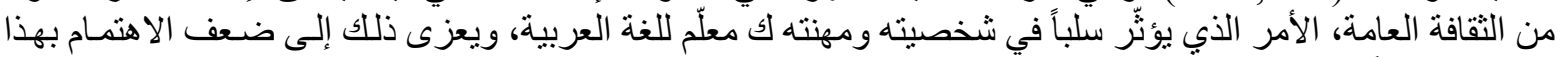

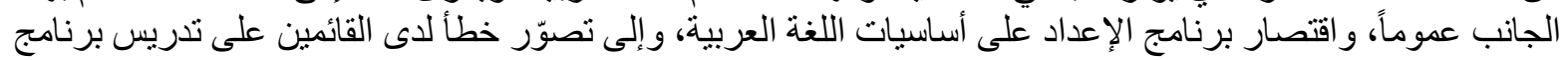
الإعداد.

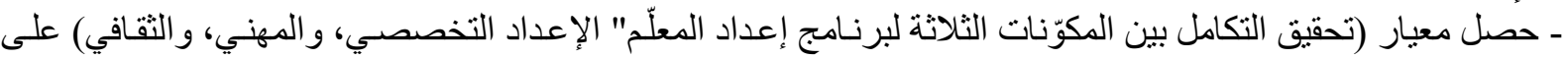

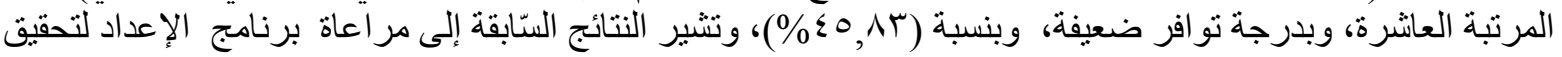

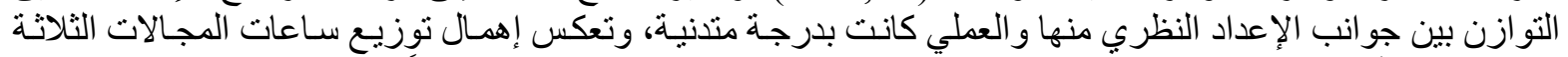

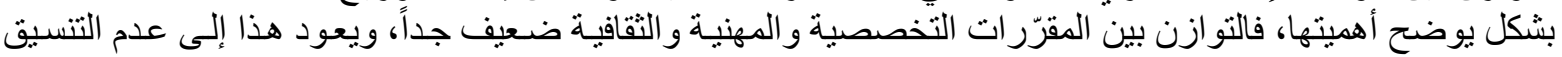

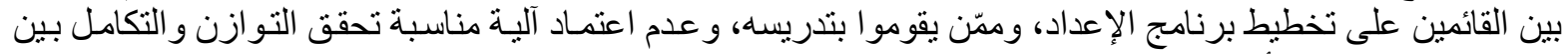

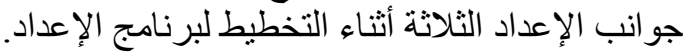

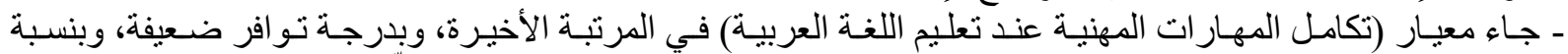

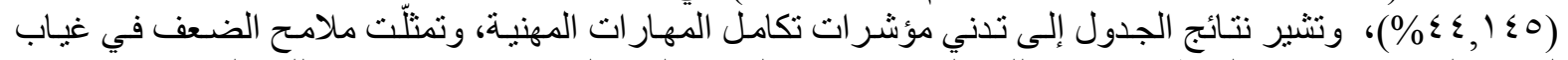

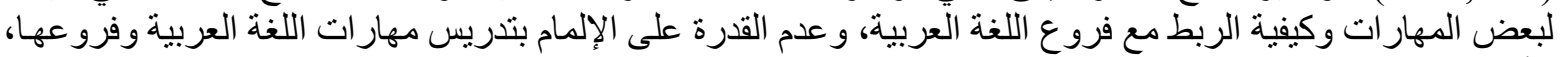

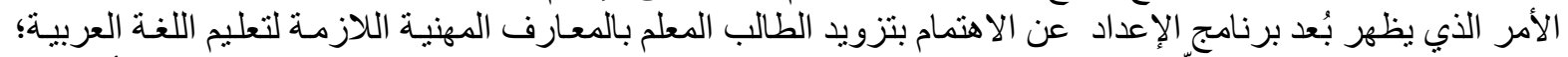

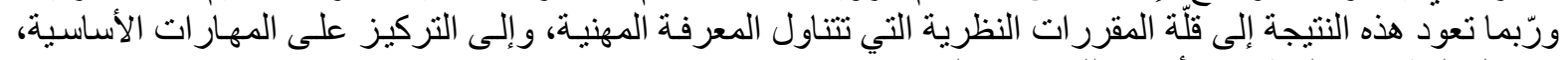
و إغفال التطبيقات الوظيفية الأخرى للمهار اتلة المهنية.

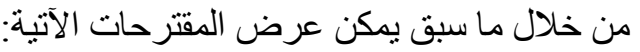

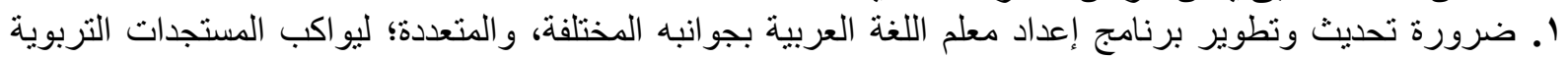

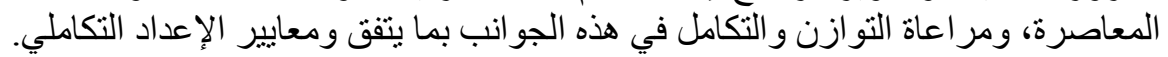

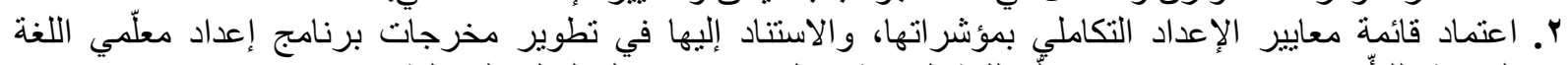

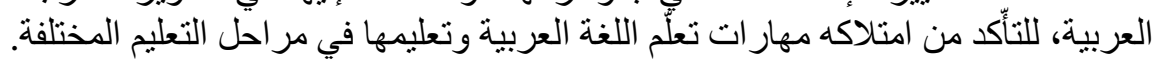

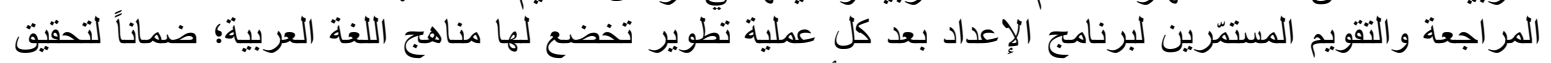

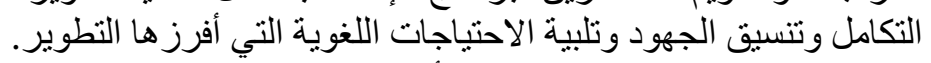

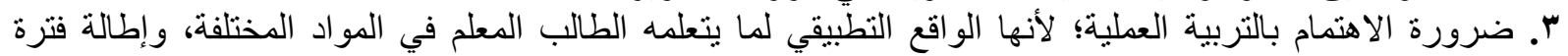

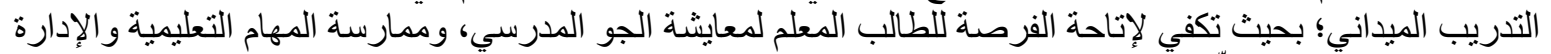

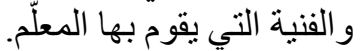
؛. القيام بدر استات مماتلة تبحثث في جو انب الإعداد الأخرى لمعلّمي المو اد الدراسية الأخرى. 


\section{المصادر}

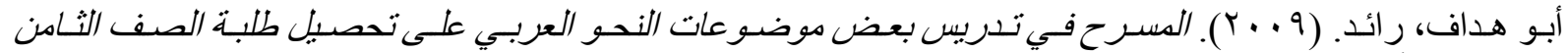

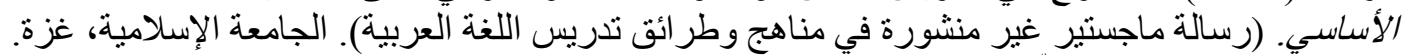

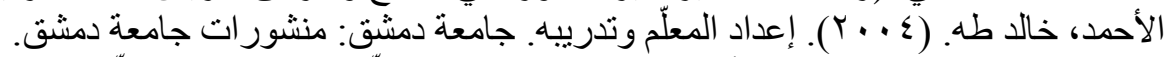

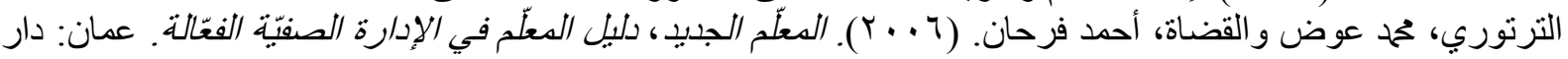

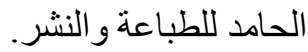

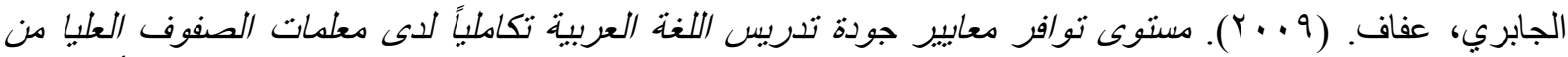

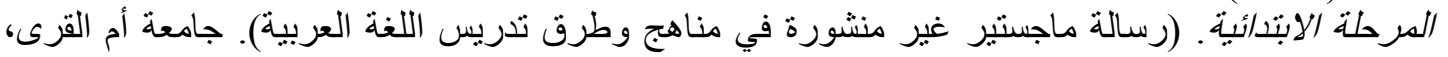

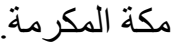

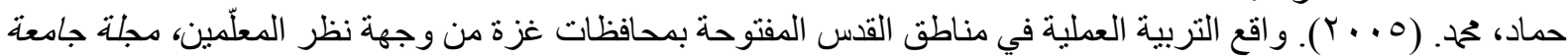

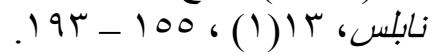

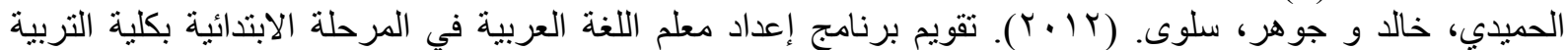

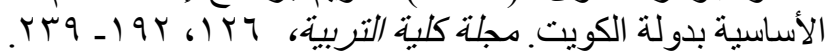

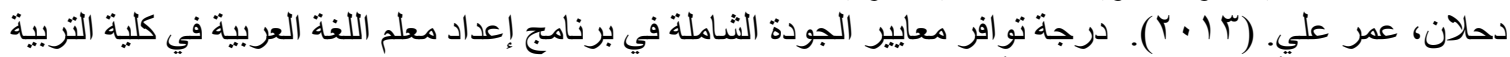

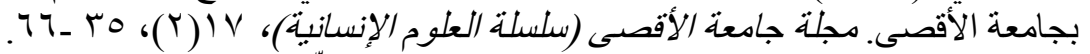

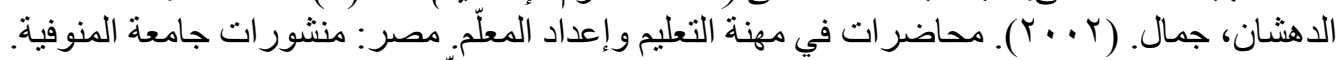

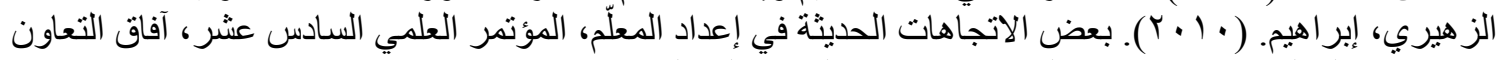

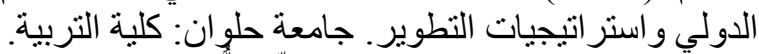

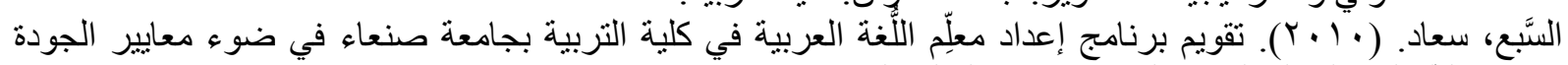

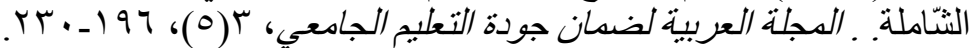

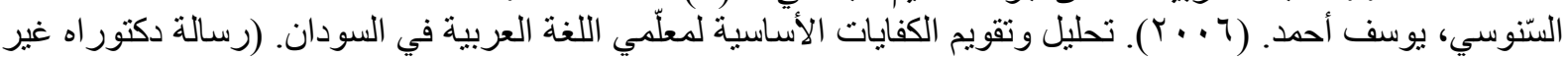

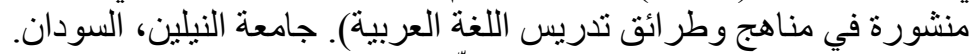

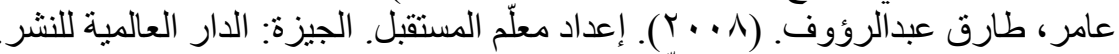

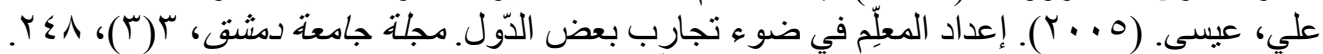

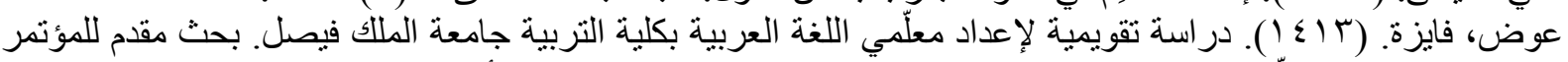

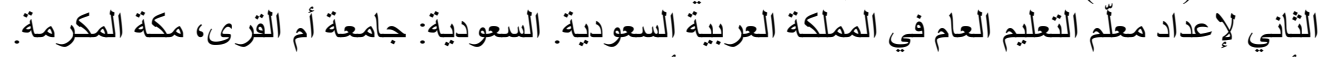

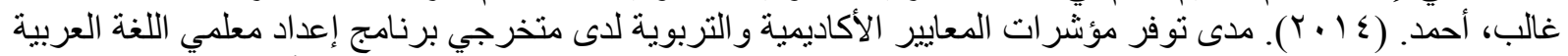

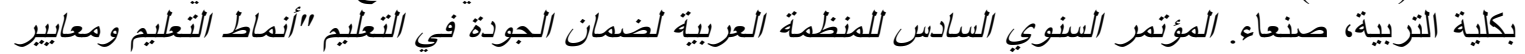

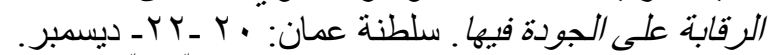

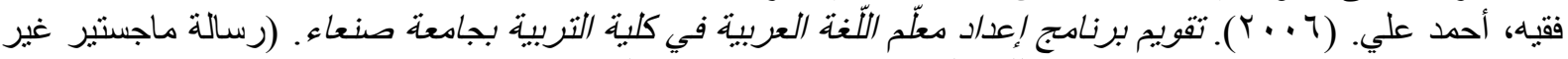

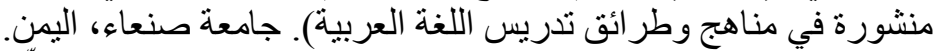

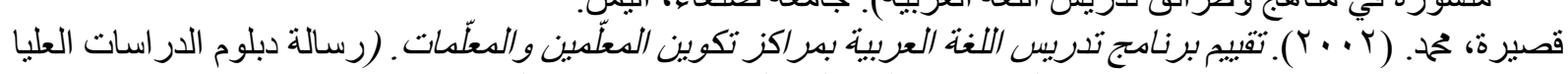

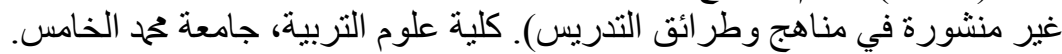

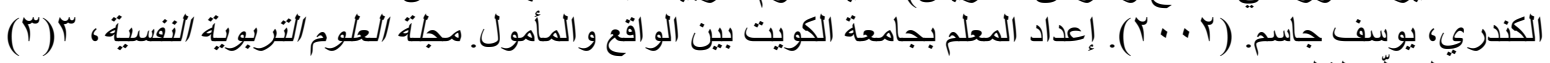

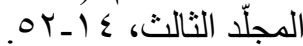
كنعان، أحمد علي. (1) (1) (1). تقويم إعداد معلّم رياض الأطفال وتأهيله وفق متطلبات الجودة، مجلة اتحاد الجامعات العربية

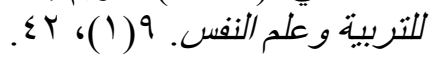

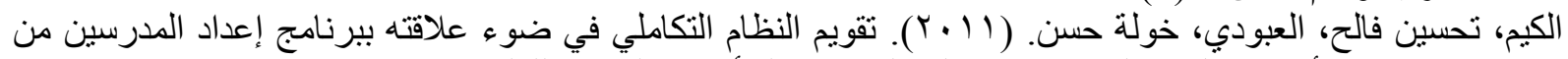

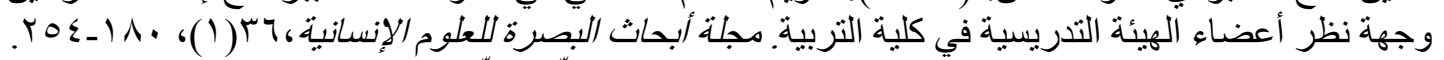

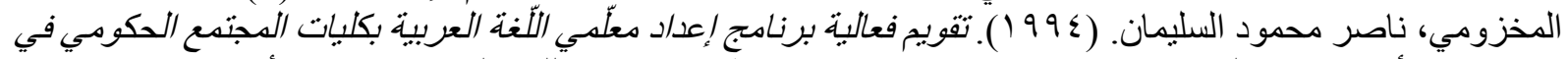
الأردن. (رسالة دكتوراه غير منشورة في مناهج وطرق تدريس الثرنية اللغة العربية). جامعة أم درمان الإسلامية:

$$
\text { الاردن. }
$$

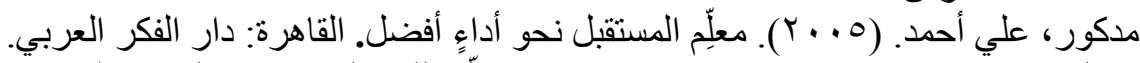

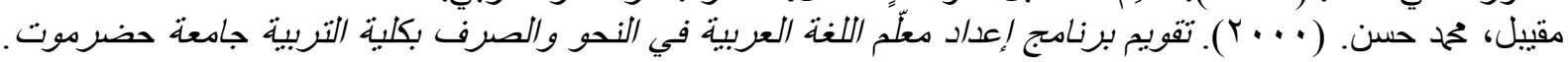

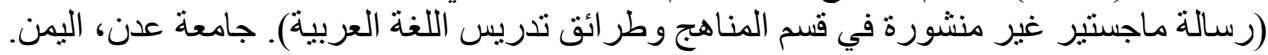

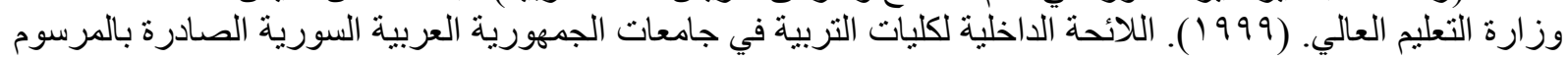

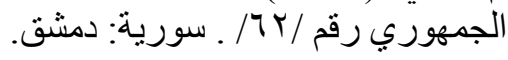




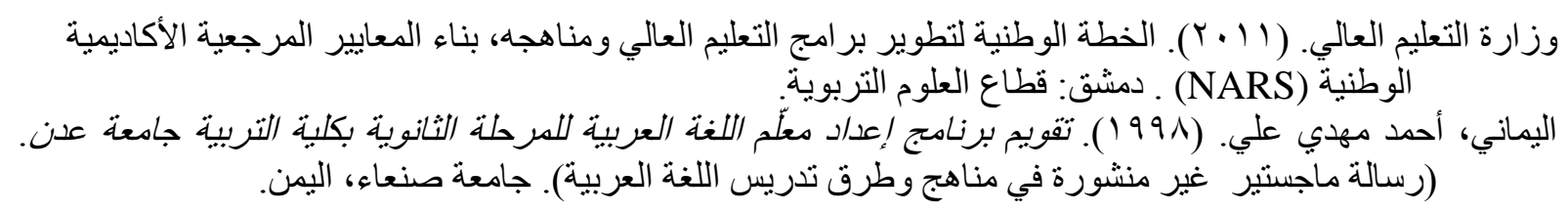

\section{References}

Abu Haddaf, R. (2009). Theater in teaching some topics of Arabic grammar for the Achievement of eighth grade basic students. (Unpublished Master Thesis in Curricula and Methods of Arabic Teaching language). The Islamic University, Palestine.

Al-Ahmad, K. (2004). Teacher Training and Preparation. Damascus University: Damascus University Publication.

Al-Dahshan, J. (2002). Lectures in the profession of education and teacher preparation. Egypt: University of Menoufia publications.

Al-Hamidi, K. \& Salwa, J. (2012). Evaluation of the program for the preparation of the Arabic language teacher in the elementary stage at the College of basic education in the state of Kuwait. Kuwait University Journal, 28(126), 223-271.

Al-Jabri, A. (2009). Level of availability of quality standards for integrative teaching-Arabic Language among teachers in the upper grades of the elementary stage. (Unpunished Master Thesis in Curricula and methods of teaching Arabic language). Umm Al-Qura University, Makkah Al-Mukarramah.

Al-kandari, Y. (2002). Preparing the teacher at Kuwait University between reality and aspirations. Journal of Education and Psychological, 3(3), 14-52.

Al-Kim, T. \& Al-Aboudi, K. (2011). Evaluation of the Integrative system in the light of its relationship to teacher preparation programs from the Viewpoint of faculty members in the college of education. Basra Research Journal of Humanities, 36(1), 180- 254.

Al-Makhzoumi, N. (1994). Evaluating the effectiveness of Arabic Language teacher training programs at government community colleges in Jordan. (Unpublished Doctoral Thesis in Curricula and methods of teaching Arabic language. Umm Darmman Islamic University, Jordan.

Al-Sabea, S., Ghalib, A. \& Abdh, S. (2010). Evaluation Of the Arabic language teacher preparation program at the college of education at sana a University in the light of comprehensive quality standards. The Arabic Journal for Quality Assurance of Education. 3(5), 196-230.

Al-Tarturi, M. \& Judges, A. (2006). The New teacher, A Teacher`s Guide to Effective Classroom Management. Amman: Dar Al Hamid printing and Publishing.

Al-Yamani, A. (1998). Evaluation of the Arabic language teacher preparation Program for the Secondary stage, faculty of education University of Aden. (Unpublished Master Thesis in Curricula and methods of teaching Arabic language). Sana`a University: AlYamen.

Al-Zuhairi, I. (2010). Some recent trends in teacher preparation, Sixteen Scientific Conference, prospects for International Cooperation and Development Strategies. Helwan University: Faculty of education. 
Dahlan, O. (2013). The degree of availability of the comprehensive quality standards in The Arabic language teacher preparation program at the College of education at Al-Aqsa University, second edition. Al-Aqsa Magazine (Humanities Series), 17(2), 35-66.

Hammad, M. (2005). The reality of practical education in the open Jerusalem areas in the governorates of Gaza from the viewpoint of teachers, Nablus University Journal, 30(1), 155-193.

Higher Education. (1999). The internal regulations for colleges of education in the University of the Syrian Arab Republic. Republic Decree, 36(1), 44.

Kanaan, A. (2011). Evaluation of kindergarten teacher preparation and rehabilitation According to quality requirements. Journal of the federation of Arab Universities for Education and Psychology, 9(1), 42.

Kaserah, M. (2002). The evaluation of the Arabic language teaching program at male and female teacher training centers. (Unpublished diploma thesis in Curricula and teaching methods). Mohammed University, Rabat.

Madkour, A. (2005). Teacher of the future towards better performance. Cairo: Arab thought Center.

Ministry of Higher Education. (2011). National plan for the Development of higher education Programs and Curricula, Building Academic Standards (NARS). Damascus: education sciences sector.

Muqible, M. (2000). Evaluation of the Arabic teacher's preparation and Grammar program in the faculty of education Hadramout University. (Unpublished master thesis in Curricula and methods of teaching Arabic language). College of education, University of Aden.

\section{Foreign References}

Jacob, B. (2001). Providing the scaffold amondel for early childhood preparation. Pacific Journal of Teacher Education, 36(91), 191-208. Retrieved from http://www.nbpts.org/ research $\backslash$

Minor, L. Onquegbuzie, A., Witcher, A. \& James.T. (2002). Pre-service teachers educational Beliefs and their perceptions of Characteristics of effective teacher. Journal of Education for Teacher, 92(21), 116-127.

Missouri Department of Elementary \& Secondary Education. (2006). Missouri Standards for Teacher Education Program Benchmarks for Preliminary Teacher Education. Australia: Melbourne Publisher.

Timperley, H. (2011). Fundamentals of the Development of a National Professional Development Framework for Teachers and School Leaders, ALTSL. Australia: Melbourne.

UNDP\RBAS. (2003). Building a knowledge society. New York: The Arab human development report UNDPIRBAS. Retrieved from http//:hdr.orglen\reports\regional reports\Arab states\Arabs 2003-en. Pdf. Accessed on April 4, 2009. 